\title{
Cross-Border MERGERS \& ACQUISITIONS: THE FACTS AS A GUIDE FOR INTERNATIONAL ECONOMICS
}

\author{
STEVEN BRAKMAN \\ HARRY GARRETSEN \\ CHARLES VAN MARREWIJK
}

CESIFO WORKING PAPER NO. 1823

CATEGORY 10: EMPIRICAL AND THEORETICAL METHODS

OCTOBER 2006

An electronic version of the paper may be downloaded

- from the SSRN website:

www.SSRN.com

- from the RePEc website:

www.RePEc.org

- from the CESifo website:

www.CESifo-group.de 


\title{
CROSS-BORDER MERGERS \& ACQUISITIONS: THE FACTS AS A GUIDE FOR INTERNATIONAL ECONOMICS
}

\begin{abstract}
Using a detailed and large data set on cross-border merger and acquisitions we discuss the relationship between theory and observed empirical characteristics:

(i) most FDI is in the form of M\&As, (ii) firms engaged in M\&As seem to be 'marketseeking', (iii) M\&As come in waves (the most recent wave is still unfolding), (iv) economic integration (international deregulation) stimulated M\&As, (v) the size of and inequality between M\&As grows over time.

Our contention in this chapter is that these stylized facts drive and should drive recent theoretical contributions in the field of international economics that try to understand crossborder mergers and acquisitions. Although some models (notably Neary, 2003) explain a number of the characteristics, a full-fledged model of cross-border M\&As that, at least in principle, can deal with all the characteristics is still lacking.
\end{abstract}

JEL Code: F23.

Steven Brakman
Department of Economics
University of Groningen
P.O. Box 800
9700 AV Groningen
The Netherlands
s.brakman@rug.nl

Charles van Marrewijk

Erasmus University Rotterdam

Department of Economics

H8-10, P.O. Box 1738

3000 DR Rotterdam

The Netherlands

vanmarrewijk@few.eur.nl
Harry Garretsen

Utrecht School of Economics

Utrecht University

Vredenbrug 138

3511 BG Utrecht

The Netherlands

h.garretsen@econ.uu.nl

We would like to thank Utz Weitzel for his help with the Thomson data-set. 


\section{$1 \quad$ Introduction}

Theoretical developments in international economics are sometimes motivated by empirical findings. The 'new trade theory', for example, was to a large extent inspired by empirical work on intra-industry trade (Neary, 2004b). This also holds for the recent outburst of research on foreign direct investment (FDI) as one of the driving forces behind the current wave of globalization. Many observers have noted that FDI grows much faster than world merchandise trade (Barba Navaretti and Venables, 2004). This is clearly a stylized fact in search of an explanation. For years, students of FDI used the OLI-categorisation scheme of Dunning (1993) to understand why firms engage in FDI. Notwithstanding its usefulness in the case of FDI, a categorisation scheme is not a model. New theories are being developed in which the firm's decision on FDI engagement is determined in a full-fledged micro-economic model.

Figure 1 Distribution of different types of FDI

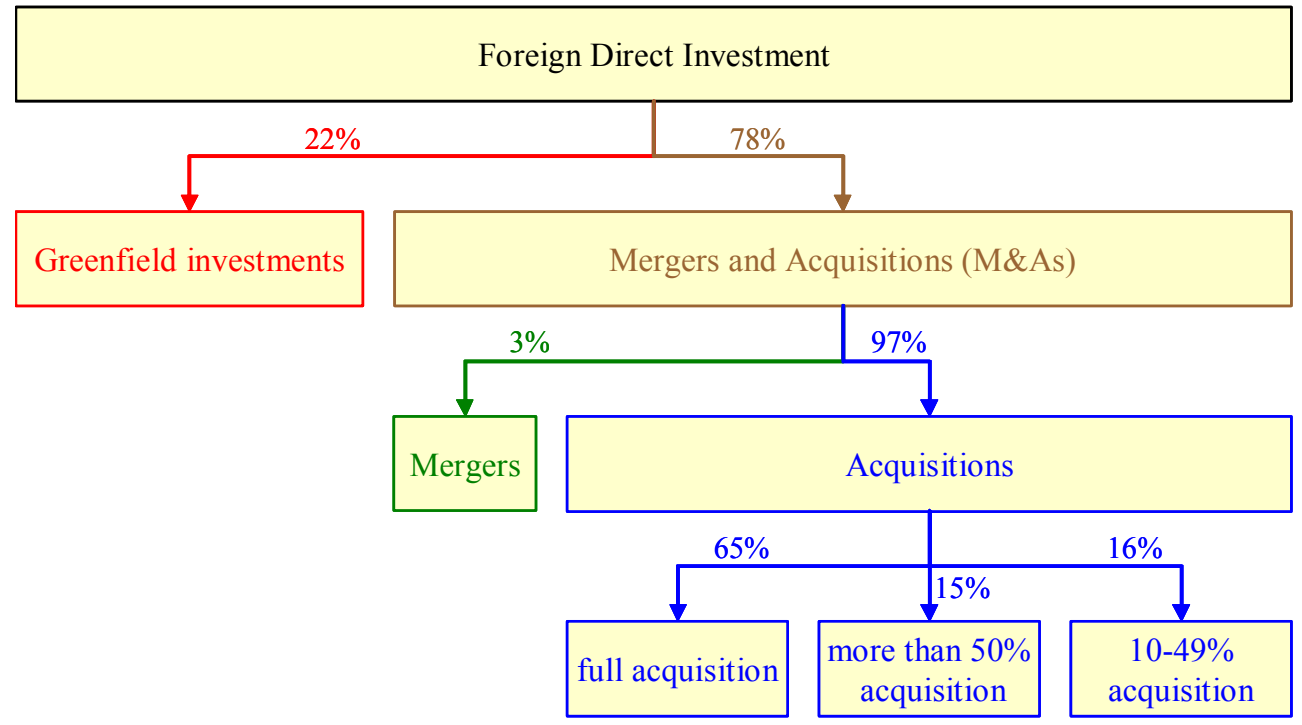

Source: Brakman et al. (2006); data: UNCTAD (2000); 78-22\% in value terms, other \% in \# of deals

Interestingly, looking at FDI as a broad category obscures the fact that most FDI is in the form of so-called cross-border Mergers \& Acquisitions (henceforth: M\&As). Figure 1 shows a decomposition of FDI from which it is clear that M\&As constitute the bulk of FDI, whereas greenfield FDI is less important than M\&As. The main difference between these two investments is that in an M\&A "control of assets and operations is transferred from a local to a foreign company, the former becoming an affiliate of the latter" (UNCTAD, 2000, p. 99). Only recently models in international 
economics have been developed that enable us to understand M\&As (Neary, 2004b). Neary's model takes the standard explanations for M\&As a step further. Usually two motives are mentioned to explain M\&As: a strategic motive (reduce competition) and an efficiency motive (cost reductions). An explanation of cross-border M\&As, however, also has to explain the cross-border part of the deals. Trade theory suggests that comparative advantage could be included in full explanations of M\&As, see Neary (2004a). A different, equally novel line of research in international economics (see Barba-Navaretti and Venables, 2004, or Helpman, 2006, for excellent surveys), seeks to understand the conditions under which firms decide to locate (part of) their production abroad (the off-shoring decision). When they decide to off-shore, some firms do so under the flag of FDI, while other firms go for outsourcing. In this literature, and in contrast to the empirical relevance illustrated in Figure 1, the role of cross-border M\&As is, however, largely ignored. The aim of this chapter is to present stylized facts on cross-border M\&As. This is not only interesting in its own right (see also Evenett, 2004), but may also act as a guide for the recent upsurge of interest in FDI and its alternatives in international economics regarding the facts that the modern theory of FDI should be able to explain. When highlighting the stylized facts in this chapter, we therefore briefly point out those FDI models in international economics that are able to cope with the facts under consideration.

We proceed as follows. Section 2 presents basic characteristics of M\&As using the database of Thomson Financial Securities Data (Thomson, hereafter). The advantage of this source over UNCTAD data is that it consists of individual data on each and every M\&A, enabling us to look at M\&As at a very detailed level. Section 3 provides information at the country level. Section 4 looks at the regional composition of target and acquirer, which are both typically to be found in the OECD countries. Section 5 confronts gross M\&As with net M\&As and discusses some developments over time, confirming that emerging markets, like China and Eastern Europe, are increasingly becoming net targets. Section 6 argues that the inequality within the set of M\&As tends to increase over time. Section 7 discusses the characteristics of firms involved in FDI. Section 8, finally, concludes and summarizes our findings. 


\section{Cross-border M\&As: basic characteristics}

Our overview of the structure and developments of cross-border M\&As is based on Thomson's Global Mergers and Acquisitions database, which provides the best and most extensive data source for M\&As to date. Thomson gathers information on M\&As exceeding 1 million US dollar. Its main sources of information are financial newspapers and specialized agencies like Bloomberg and Reuters. Our Thomson data set begins in 1979 and ends in August 2006. Initially, Thomson focused on American M\&As. Systematic M\&A data for almost all countries is available for about the last 20 years. In presenting the data we therefore focus on the period $1986-2005$, usually grouped in four five-year sub-periods to mitigate the large annual fluctuations characteristic of M\&As and to enable us to discern longer term trends.

Table 1 Overview of cross-border M\&As

\begin{tabular}{|c|c|c|}
\hline & \# of deals & per cent \\
\hline Cross-border M\&As, 1986-2005 & 27,541 & \\
\hline Effective M\&As & 27,461 & 99.7 \\
\hline Average per cent of shares acquired & & 75.5 \\
\hline Average per cent of shares owned after deal & & 80.1 \\
\hline \# of tender offers & 2,476 & 9.0 \\
\hline \# horizontal M\&As (2-digit level) & 13,605 & 49.4 \\
\hline $\begin{array}{l}\text { Public status of target } \\
\text { government } \\
\text { joint venture } \\
\text { subsidiary } \\
\text { public } \\
\text { private } \\
\text { unknown / other }\end{array}$ & $\begin{array}{r}658 \\
977 \\
11,053 \\
7,343 \\
7,489 \\
21\end{array}$ & $\begin{array}{r}2.4 \\
3.5 \\
40.1 \\
26.7 \\
27.2 \\
0.1\end{array}$ \\
\hline $\begin{array}{l}\text { Public status of acquirer } \\
\text { government } \\
\text { joint venture } \\
\text { subsidiary } \\
\text { public } \\
\text { private } \\
\text { unknown / other }\end{array}$ & $\begin{array}{r}298 \\
499 \\
6,814 \\
15,796 \\
4,067 \\
67\end{array}$ & $\begin{array}{r}1.1 \\
1.8 \\
24.7 \\
57.4 \\
14.8 \\
0.2\end{array}$ \\
\hline $\begin{array}{l}\text { \# of deals involving cash } \\
\text { if so average share of payment }\end{array}$ & 25,665 & $\begin{array}{l}93.2 \\
94.4\end{array}$ \\
\hline $\begin{array}{l}\text { \# of deals involving stock } \\
\text { if so average share of payment }\end{array}$ & 2,635 & $\begin{array}{r}9.6 \\
73.1\end{array}$ \\
\hline
\end{tabular}


We collected information on all completed / unconditional cross-border M\&As with a deal value of at least $\$ 10$ million. In the period 1986 - 2005 this provided us with 27,541 cross-border M\&As, see the overview in Table 1.

There is usually no or only a very short time difference between the date of announcement of an M\&A deal and the date the deal is effective (such that 99.7 per cent of the deals is effective). The announced date is the same as the effective date for about 38 per cent of the M\&A deals. On average the difference between these to dates is 0.18 year. We therefore used the date of announcement for classifying the M\&A deals over time, see also Brakman, Garretsen, and van Marrewijk (2005, 2006). In general, a large share of a company (on average 75.5 per cent) is acquired by the deal, leading to a majority ownership after the deal is completed (on average owning 80.1 per cent of the acquired company). This indicates that most firms already have 'intimate' knowledge of the firm that is acquired. Payment for the acquisition usually involves cash (93.2 per cent of the deals) and, if so, it is usually completely paid for in cash (on average 94.4 per cent of the deals involving cash is paid for in cash). Payment of the deal using shares occurs regularly ( 9.6 per cent of the deals) and, if so, it is usually completely paid for in shares (on average 73.1 per cent of the deals involving stocks is paid for in stocks). The fact that many takeovers are financed with cash does not imply that shares are not important in those deals: raising cash is very much facilitated if stock prices of the firms involved are high. This might be the motive to announcing takeovers before the actual takeover takes place; announcements tend to affect share prices in an upward direction (see also Box 1). ${ }^{1}$

\section{Box 1 Cross-border M\&A profitability}

For this chapter it is instructive to present a simple way of looking at a cross-border M\&A. It is more a way of organizing thoughts than a complete model, but it illustrates the key issues involved. Let " 1 " and " 0 " indicate the post- and pre-merger situation, respectively. Then the gain of taking over a Home firm, $G_{H}$, by a foreign firm is given by:

\footnotetext{
${ }^{1}$ As to (negative) relation between profits and share prices w.r.t. M\&As see Fridolfsson and Stennek (2005).
} 


$$
G_{H}=\left[\pi_{1}^{*}(n-1, n * .)-\pi_{0}^{*}(n, n * \mid)\right]-\pi_{0}(n, n * \mid .)>0
$$

The first term (in square brackets) relates to the gain in profitability from reduced competition by taking over the domestic firm: the number of domestic firms is reduced by 1 , from $n$ to (n-1). The number of foreign firms, $n^{*}$, does not change. The second term indicates the cost of acquiring the domestic firm, This is a function of profits of the target - the more profitable a target is, the higher the take-over costs and the cost of financing the take-over. If the acquirer has a windfall gain, for example, higher share prices due to the takeover, the finance costs are smaller The $\mid$. indicates that other variables are taken as given. The balance between the change in profits and the costs involved in the M\&A determines whether or not a takeover will take place. Whether the increase in profits really materializes after the M\&A has taken place is another issue, but the equation illustrates how in international economics (the equation is taken from Neary, 2004a) the firm decision on whether or not to engage in a cross border M\&A is very simple. The firm (and its organizational set-up) itself is something of a black box and the focus is on how changes in the external environment (fall in transportation costs, lowering of tariffs) might have an impact on equation (1), and thus on the M\&A decision.

There are substantial differences between the public status of acquiring and target firms. The majority of acquiring firms are public companies (57.4 per cent), followed by subsidiaries (24.7 per cent), and private firms (14.8 per cent), respectively. The target company, on the other hand, is usually a subsidiary (40.1 per cent), followed by a private company (27.2 per cent) and a public company (26.7 per cent), respectively. The share of subsidiaries and private companies among the target companies is therefore substantially larger and the share of public companies is substantially lower.

To classify M\&As between horizontal and other types of deals (be they vertical or conglomerate), we used the SIC classification of target and acquirer as provided by Thomson at the 2-digit level; a deal is therefore an horizontal M\&A in our classification if the acquirer and target are active in the same 2-digit sector. On average, about half of the M\&As are horizontal deals (49.4 per cent, see below for 
further details). Thus to a large extent investments take place in the same sector. One can speculate why this might be the case. Strategic motives may of course be at work here. but as we will argue below the most likely explanation is probably that most cross-border M\&A belong to the category of market-seeking FDI. Taking one of your competitors out of the market reduces competition and increases profits. Buying a firm outside one's own sector might be motivated by an efficiency motive: it can be profitable to control a larger part of the value chain. Both motives increase profits after the take-over. We also argue that, since most cross-border M\&As belong to the category of horizontal FDI, market-seeking motives play a dominant role in M\&As.

Figure 2 Horizontal (2-digit) cross-border M\&As; share of total, \# of deals and value

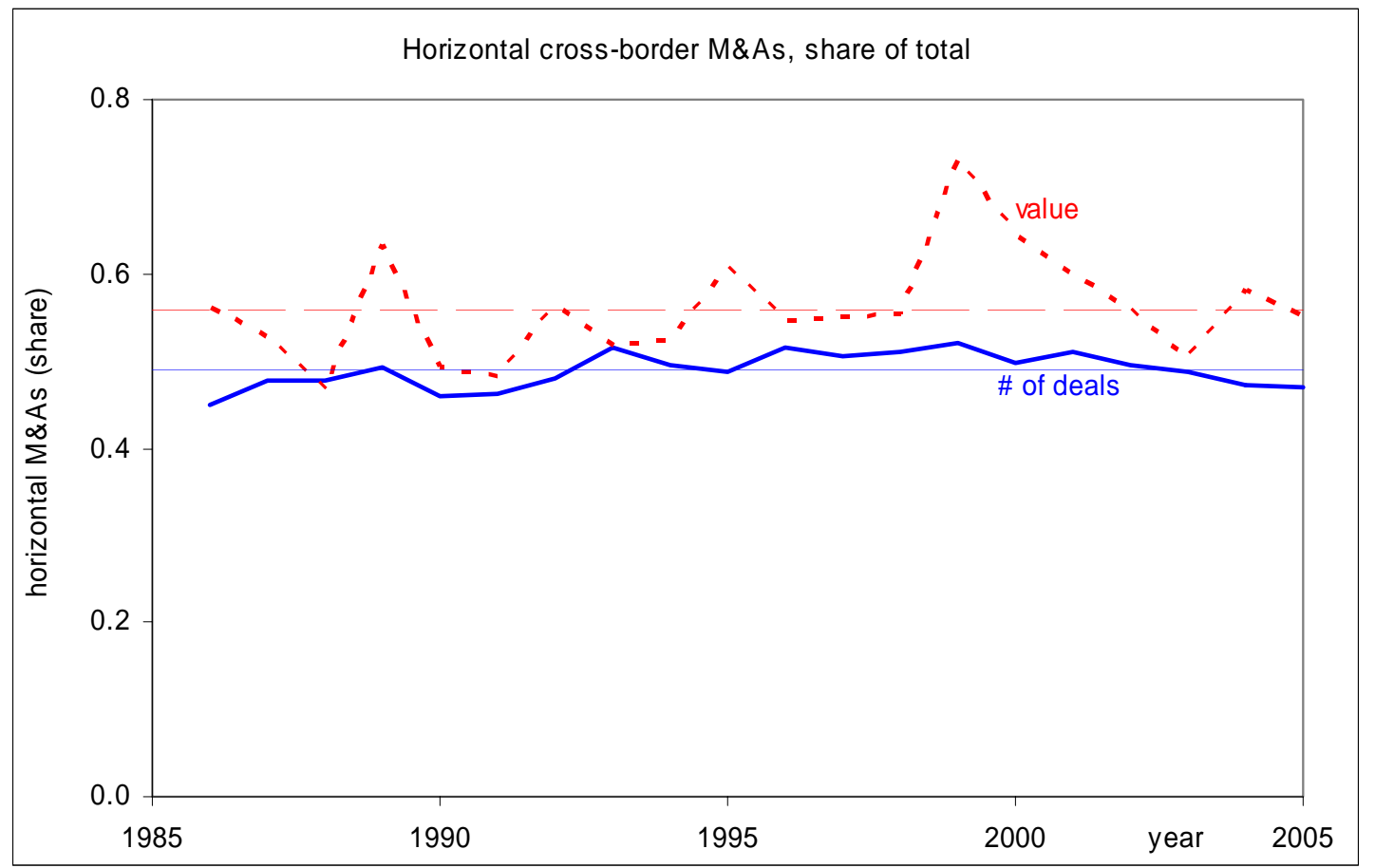

Horizontal lines indicate averages for the period 1986-2005.

Figure 2 illustrates that the share of horizontal M\&As is very stable over time when measured using the number of deals; fluctuating relatively little around the average of 49 per cent, ranging from a low of 45.1 per cent in 1986 to a high of 51.5 per cent in 1996. Horizontal M\&As are substantially more volatile when measured using the value of the deals; fluctuating around the average of 56 per cent, ranging from a low of 46.7 per cent in 1988 to a high of 73.0 per cent in 1999. Using either measure, we find little support for the argument that the share of horizontal M\&As is declining. Those who would argue that the value of horizontal M\&As has declined since 1999 
are obviously obscuring the fact that this peak in 1999 is not representative over a longer time horizon. The current (2005) value of horizontal M\&As of 55.2 per cent is very close to the long run average of 56 per cent. From an international economics' perspective, see our introduction, the question is if existing theories of FDI can explain the dominance of horizontal FDI. At first sight, this is not the case. Assuming that during our sample period 1985-2005 trade costs broadly defined have, if anything, decreased the standard FDI model then predicts that horizontal FDI should become less important. With falling trade costs foreign markets might ceteris paribus be better served by exporting instead of FDI, and in the well-known proximityconcentration trade-off, a drop in trade costs shifts the trade-off in favor of exporting. However, Neary (2005) shows that falling trade costs might still explain the rise of horizontal FDI, and thus of the bulk of cross-border M\&As, once we allow for an FDI model that explicitly incorporates the possibility of cross-border M\&As instead of merely looking at FDI as a black box (see Neary, 2004a).

Figure 3 Cross-border M\&As, 1985 - 2005; \# of deals and value

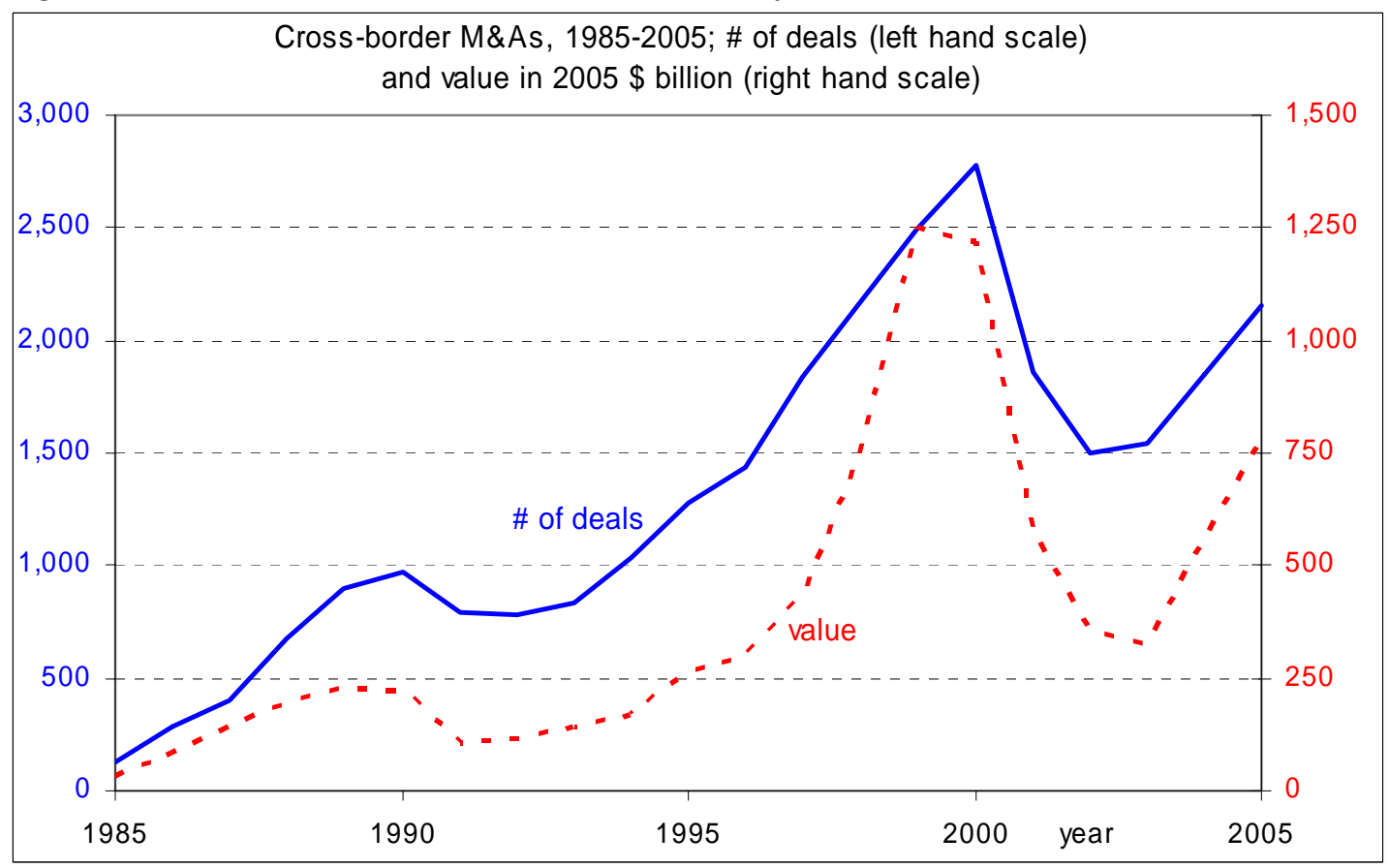

An historical perspective reveals a remarkable characteristic of M\&As. Figure 2 depicts the evolution of all cross-border M\&As over time, both measured as the number of deals and the value of deals (in constant 2005 \$ bn., using the US GDP deflator). Clearly, there is substantial variation over time, with periods of rapid increase followed by periods of rapid decline. Five merger waves have been identified 
during the $20^{\text {th }}$ century, three of which are recent (Andrade, Mitchell, and Stafford, 2001). The $3^{\text {rd }}$ wave took place in the late 1960 -early 1970s. The $4^{\text {th }}$ wave ran from about the mid 1980s until 1990. The $5^{\text {th }}$ wave started around 1995 and ended in 2000 with the collapse of the "new economy". Figure 3 shows that a subsequent $6^{\text {th }}$ (still ongoing) merger wave started in the $21^{\text {st }}$ century around 2003. Note, that the data used in this chapter cover the last two waves.

Merger waves are positively correlated with increases in share prices and p/e ratios, and with the overall business cycle in general. However, the causality of the relation is not always clear. On the one hand, an upswing of the business cycle increases share prices, and high share prices reduce the cost of financing a M\&A. On the other hand the same upswing of the business-cycle increases the profits of the target and increase take-over costs (see also Box 1). When one sticks to standard M\&A motives, like the efficiency argument, it is rather difficult to explain the synchronicity of M\&As. Gugler et al. (2004) argue that merger waves can be understood if one acknowledges that M\&As do not boost efficiency and hence do not increase shareholders' wealth. Instead, they find that M\&A waves are best looked upon as the result of overvalued shares and managerial discretion. For the case of the USA and restricting their sample to firms that are publicly traded, Andrade et al. (2001) show that with each merger wave the value of the M\&A deals (measured by firms' market capitalization) increases strongly. Merger waves in Europe seem to follow those in the USA with a short lag. During the $5^{\text {th }}$ merger wave, European firms engaged in a number of (mega) M\&As with the cross-border take-over of Mannesmann (Germany) by Vodafone (UK) for $\$ 203$ bn. in $1999 / 2000$ as to date the largest M\&A. It turns out that especially this part of M\&A waves is difficult to model. First of all, an M\&A wave must start at some point in time. Equation (1) points at a difficulty in this respect. A reduction of competition makes an M\&A profitable, which implies that it is rational to wait for other M\&As to go first, because this reduces competition and makes the next M\&A more profitable than the first one. Second, an M\&A wave must stop at some point. Both elements should be incorporated in a full M\&A model. Neary (2004a) does just that: waves have to start at some point in time or else M\&A profits are foregone. Moreover, since it is a general equilibrium model, the excess supply on the labor market following an M\&A (lower wages resulting in higher profits) finally stop the wave. 


\section{$3 \quad$ Countries and M\&As in 2005}

This section provides an overview of the currently (2005) most active countries in M\&As. There were 2,154 cross-border M\&As in 2005 with a total value of about $\$ 774$ bn. Table 2 provides an overview of the top 20 countries ranked in order of acquirer value. Not surprisingly, the United States tops the list, both in value and number of deals, acquiring 514 foreign firms with a total value of about $\$ 158$ bn (20.4 per cent of the total). The United States is also the largest target country in 2005 when measured in number of deals (356) and the second largest target in value terms $(\$ 125$ bn). The United Kingdom is the second largest acquiring country (286 deals and \$94 bn) and the largest target country in value ( $\$ 144 \mathrm{bn}$; second largest in number of deals). Among the other countries listed in Table 2 are the "usual suspects" of high income (European) countries: Spain, France, Germany, Italy, Switzerland, Netherlands, Sweden, Denmark, Norway, Israel, Australia, Canada, Japan, Russia, and Hong Kong. More remarkable, presumably, are the high ranks for Egypt, United Arab Emirates (UAE), and even tiny Luxembourg.

Table 2 Cross-border M\&As; top 20 countries in 2005 (ranked according to acquirer value)

\begin{tabular}{ll|rrr|rr}
\hline \hline & & \multicolumn{3}{|c}{ in value terms (\$ million) } & \multicolumn{2}{c}{ in \# of deals } \\
& Country & acquirer & \% of total & target & acquirer & target \\
\hline 1 & United States & 157,924 & 20.4 & 124,764 & 514 & 356 \\
2 & United Kingdom & 94,104 & 12.2 & 143,754 & 286 & 262 \\
3 & Spain & 59,953 & 7.7 & 22,531 & 49 & 58 \\
4 & France & 58,606 & 7.6 & 36,733 & 86 & 110 \\
5 & Germany & 48,081 & 6.2 & 65,053 & 79 & 136 \\
\hdashline 6 & Italy & 37,897 & 4.9 & 48,593 & 48 & 58 \\
7 & Australia & 31,722 & 4.1 & 10,048 & 137 & 106 \\
8 & Switzerland & 30,973 & 4.0 & 6,710 & 35 & 22 \\
9 & Netherlands & 28,664 & 3.7 & 32,416 & 64 & 38 \\
10 & Sweden & 19,555 & 2.5 & 17,799 & 63 & 44 \\
11 & Egypt & 16,992 & 2.2 & 2,227 & 6 & 9 \\
12 & Canada & 15,679 & 2.0 & 26,943 & 121 & 87 \\
13 & Luxembourg & 14,584 & 1.9 & 7,808 & 21 & 7 \\
14 & United Arab Emirates & 14,565 & 1.9 & 86 & 11 & 1 \\
15 & Japan & 12,034 & 1.6 & 3,538 & 70 & 26 \\
\hdashline 16 & Russia & 11,088 & 1.4 & 7,818 & 22 & 28 \\
17 & Denmark & 9,341 & 1.2 & 20,933 & 27 & 33 \\
18 & Hong Kong & 9,213 & 1.2 & 10,107 & 60 & 63 \\
19 & Israel & 8,847 & 1.1 & 2,001 & 17 & 18 \\
20 & Norway & 8,799 & 1.1 & 7,329 & 20 & 33
\end{tabular}


As suggested by the fact that the USA and the UK take the two top spots in Table 2 both as acquirer and target, there is substantial coincidence between acquirers and targets (large acquiring countries are usually also large target countries, and vice versa). Indeed, of the 20 countries listed as the largest acquirers in value terms in Table 2, fifteen also appear among the top 20 as largest targets in value terms. Only Switzerland, Egypt, UAE, Japan, and Israel would have to be replaced by Belgium, China, Turkey, Czech Rep., and South Korea. This coincidence is illustrated in Figure 4 using logarithmic scales. The figure also indicates that the Czech Rep. is indeed a relatively large target and the UAE is indeed a relatively large acquirer.

Figure 4 Cross-border M\&As; 2005, value (\$ million, log scales)

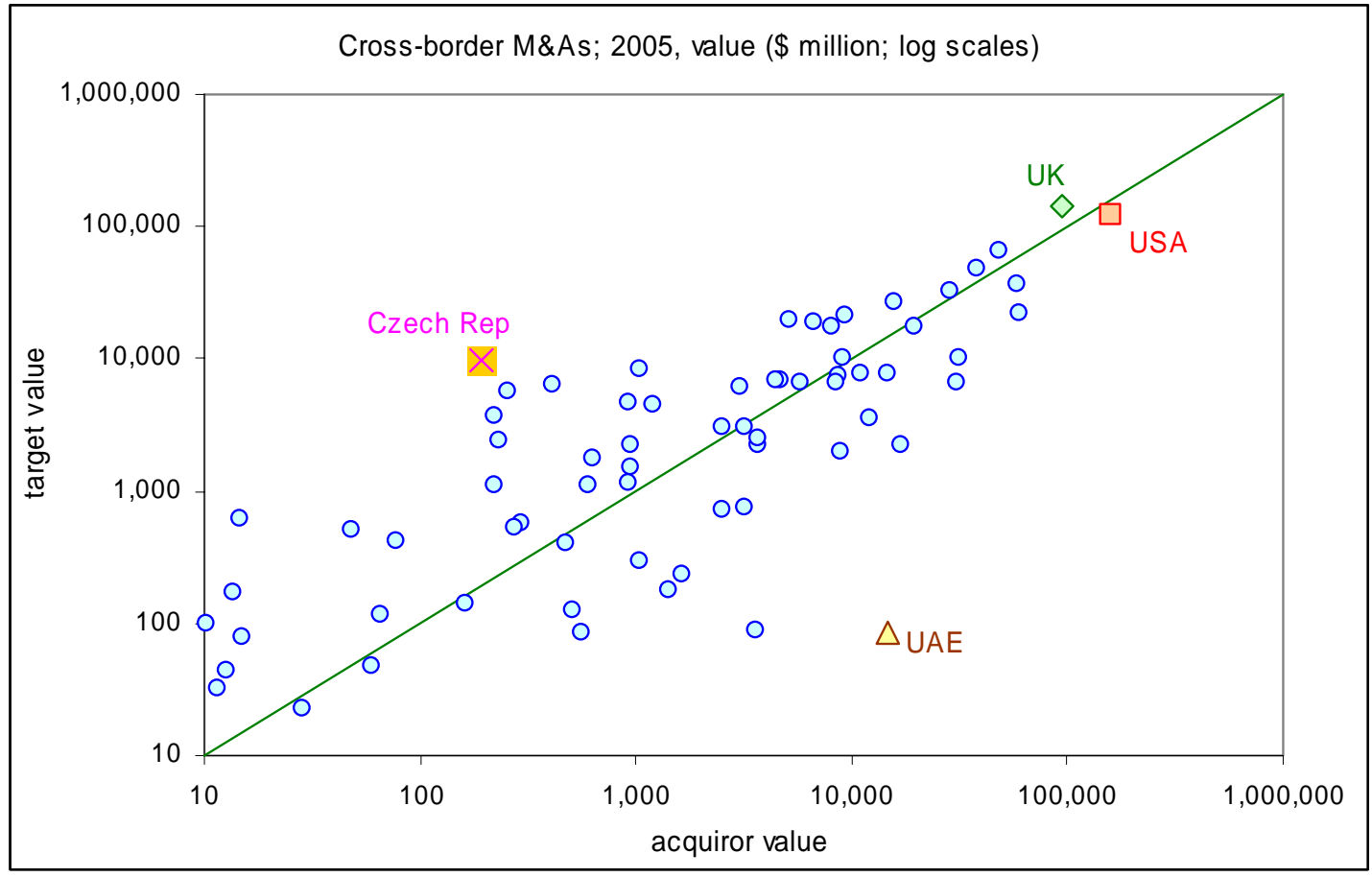

The thin line is the $45^{\circ}$ line.

What can we conclude from the fact that M\&As mostly take place between high income countries? As stated before an important classification in the literature is the difference between so-called horizontal and vertical FDI. The difference is important because in case of horizontal FDI firms are 'market-seeking' (looking for large and profitable markets), in case of vertical FDI firms have a 'factor-market' motive. In the former case firms are interested in the high wages of consumer, instead of low cost in factor markets (for example low wages) as in the latter case. Thus, both forms need very different models. As horizontal FDI seems to dominate the data, models that stress 'market-seeking' reasons to engage in M\&As are potentially the most 
appropriate for empirical research. Having acknowledged this, see also the previous section, these models have trouble explaining FDI in the face of increased economic integration (falling trade costs), see also Evenett (2004, p. 427). It is here that the models in international economics might gain (Neary, 2005) from differentiating more clearly between various forms of FDI, notably by including cross-border M\&As as a separate category of FDI.

\section{Regional distribution of cross-border M\&As}

In section 3 we showed that the majority of cross border M\&As is between relatively rich countries. There is, however, in the public debate on off-shoring, which thus includes all forms of FDI and thus also cross border M\&As as well as outsourcing, a strong undercurrent that looks at off shoring and thereby at FDI and its main component cross border M\&A as "threatening". Workers in the industrialized countries would lose out because of the re-location of their jobs to other, notably lowwage countries. This fear is far from new, as illustrated by the former American presidential hopeful Ross Perot's "giant sucking sound" comments (in)famously made in 1992 on the alleged migration of jobs from the USA to Mexico. To assess these developments over time it is useful to define more or less coherent groups of countries, which we label "global regions." We identify nine global regions, namely six developing regions and three high income regions. The six developing regions are based on the World Bank's grouping in global regions (see the appendix for details):

1. EAP: East Asia and Pacific (includes China and Indonesia)

2. ECA: (East) Europe and Central Asia (includes Turkey and Russia)

3. LAC: Latin America and Caribbean (includes Brazil and Mexico)

4. MNA: Middle East and North Africa (includes Egypt)

5. SAS: South Asia (includes India)

6. SSA: Sub-Sahara Africa (includes Nigeria and South Africa)

The World Bank's group of high income countries is sub-divided into three global regions following van Marrewijk (2002, Ch. 1; see also Table A1 in the appendix):

7. AAS: AustalAsia (includes Australia, Japan, and South Korea)

8. EUR: Western Europe (includes France, UK, and Germany)

9. NAM: North America (includes Canada and USA) 
Figure 5 Regional distribution of M\&A acquirers; value, per cent of total

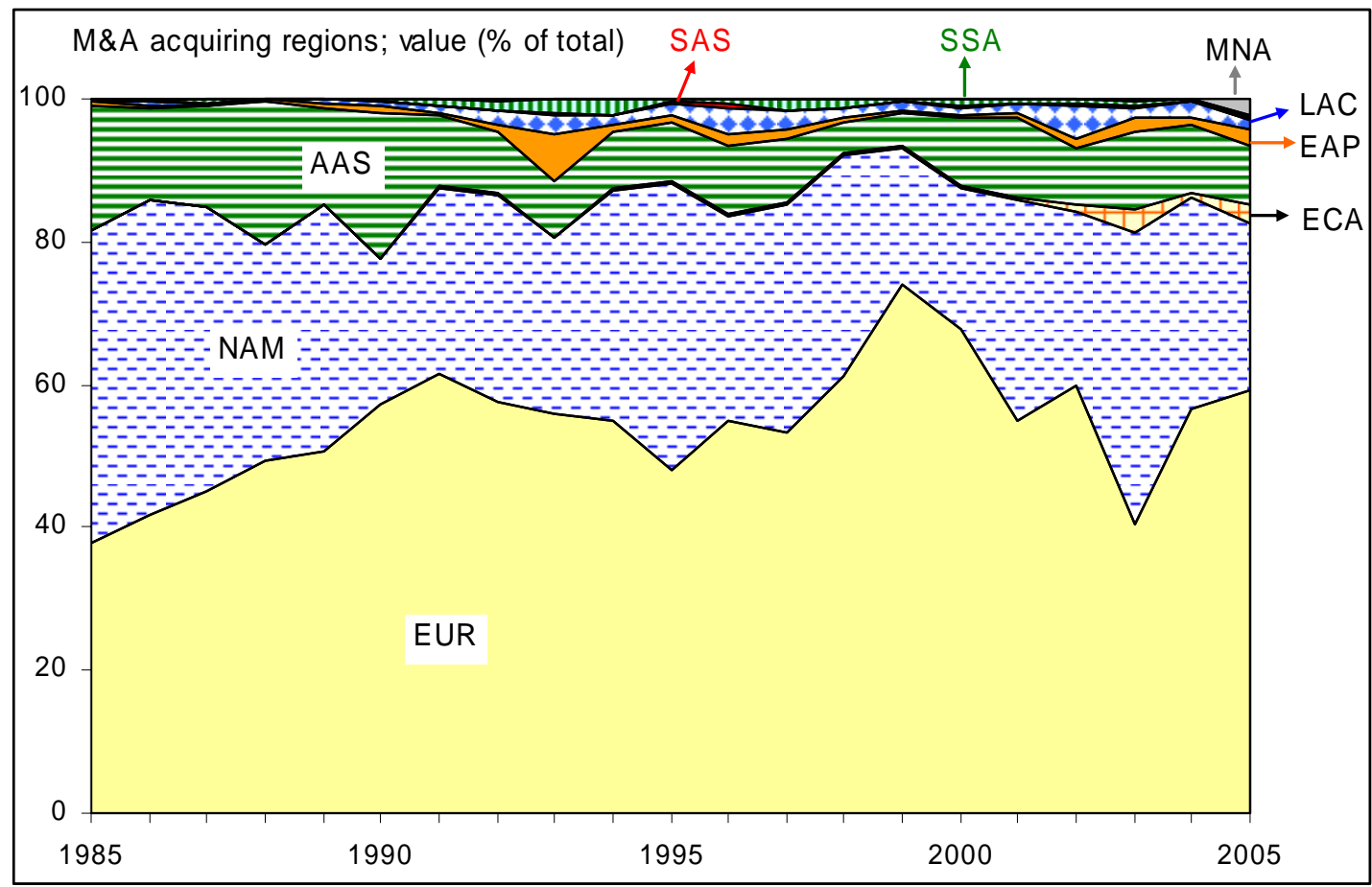

$\mathrm{EAP}=$ East Asia and Pacific; ECA = (East) Europe and Central Asia; LAC = Latin America and Caribbean; MNA = Middle East and North Africa; SAS = South Asia; SSA = Sub-Sahara Africa; AAS $=$ AustalAsia; EUR $=$ Western Europe; NAM $=$ North America.

Figure 6 Regional distribution of M\&A targets; value, per cent of total

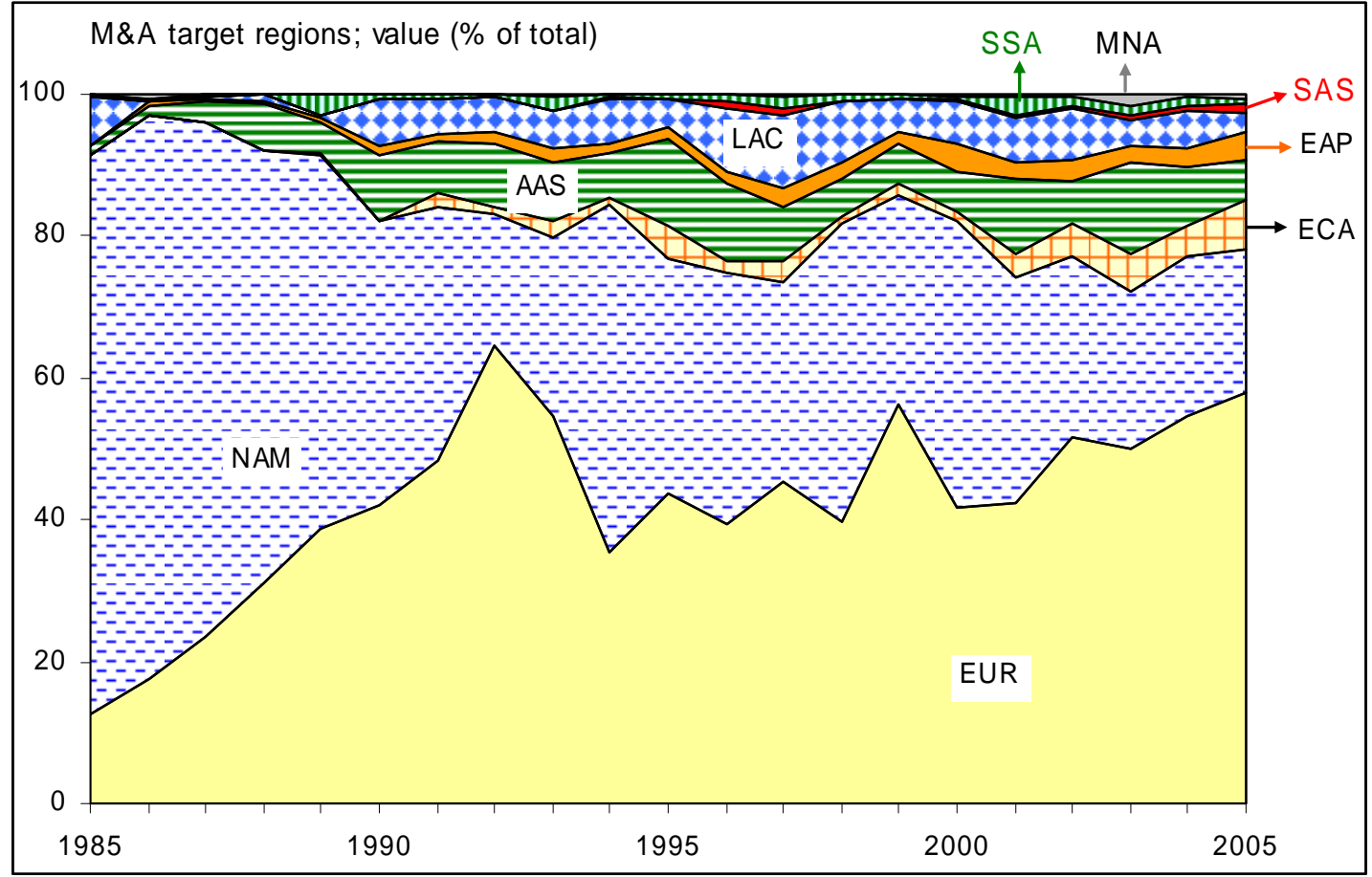

For abbreviations: see Figure 5. 
Figures 5 and 6 depict the evolution over time of the global regions in terms of acquirer and target in cross-border M\&As, as a per cent of the total value of M\&As in the respective year.

- Western Europe (EUR) is by far the largest acquirer (on average about 55 per cent of the total), followed by North America (30 per cent) and AustralAsia (10 per cent). Over time, the share of Western Europe as an acquirer has increased and of North America has decreased. At the world scale, the importance of East Asia and Pacific (EAP) and Latin America (LAC) as an acquirer is limited (between 1 and 2 per cent) and of the other global regions is minimal (less than 1 per cent). Western Europe and North America are about equally important as the world's largest target regions for M\&As, on average about 44 and 38 per cent of the world total, respectively. Western Europe has clearly become a more important target region over time, whereas North America's position has clearly declined. AustralAsia is again third (about 7 per cent), closely followed by Latin America (5 per cent). The importance of Eastern Europe as a target region has clearly increased, as has, to a lesser extent, the importance of East Asia and Pacific and Latin America. The importance of South Asia (SAS), the Middle East and North Africa (MNA), and Sub-Sahara Africa (SSA) has a target region is minimal (less than 1 per cent).

In the light of the "fear of globalization" debate that we alluded to at the beginning of this section, the increased importance of Eastern Europe and also of East Asia and the Pacific and Latin America as target region provides some evidence that cross-border M\&As are increasingly used as a vehicle to invest from high-income countries to lowincome countries. The changes are, however, (still) modest; it remains true even in our regional classification above that the vast majority of FDI takes place between and within the three high-income regions. Table 3 provides more detail in this resepect by giving the regional distribution of cross-border M\&As in percentages of the total for acquirer and target region for each of the four five-year sub-periods. It shows, for example, that EUR acquired 48.8 per cent of the cross-border M\&As in the period 1986-1990, of which 26.4 percentage point were destined for NAM and 19.8 percentage points for EUR itself. Since then EUR's share as an acquirer has been above 50 per cent, while its share as a target has been close to 50 per cent. Also note the relative importance of the intra-regional M\&As. 
Table 3 Regional distribution of cross-border M\&As; 5 year averages (\% of total)

\begin{tabular}{l|rcccccccc|r}
\hline \hline \multicolumn{1}{l}{$\begin{array}{l}\text { Average value } 2001-2005 \\
\text { acquirer }\end{array}$} & AAS & EAP & ECA & EUR & LAC & MNA & NAM & SAS & SSA & \\
\hline AAS & 3.7 & 1.0 & 0.1 & 2.5 & 0.1 & 0.0 & 2.0 & 0.0 & 0.0 & 9.6 \\
EAP & 0.4 & 0.5 & 0.0 & 0.2 & 0.1 & 0.1 & 0.0 & 0.0 & 0.0 & 1.4 \\
ECA & 0.0 & 0.0 & 1.4 & 0.2 & 0.0 & 0.0 & 0.1 & 0.0 & 0.0 & 1.7 \\
EUR & 2.1 & 0.5 & 2.9 & 34.6 & 2.0 & 0.4 & 10.2 & 0.3 & 1.1 & 54.2 \\
LAC & 0.0 & 0.0 & 0.0 & 0.0 & 1.4 & 0.0 & 0.8 & 0.0 & 0.0 & 2.2 \\
MNA & 0.0 & 0.0 & 0.0 & 0.4 & 0.0 & 0.1 & 0.0 & 0.0 & 0.0 & 0.5 \\
NAM & 2.3 & 0.7 & 0.5 & 13.3 & 1.4 & 0.1 & 11.2 & 0.2 & 0.1 & 29.8 \\
SAS & 0.0 & 0.0 & 0.0 & 0.0 & 0.0 & 0.0 & 0.0 & 0.1 & 0.1 & 0.3 \\
SSA & 0.1 & 0.0 & 0.0 & 0.1 & 0.0 & 0.0 & 0.1 & 0.0 & 0.2 & 0.5 \\
\hline & 8.8 & 2.7 & 4.9 & 51.4 & 5.1 & 0.7 & 24.3 & 0.6 & 1.5 & 100 \\
\hline
\end{tabular}

\begin{tabular}{l|rccccccccc|r}
\multicolumn{1}{l}{$\begin{array}{l}\text { Average value } 1996-2000 \\
\text { acquirer }\end{array}$} & AAS & EAP & ECA & EUR & LAC & MNA & NAM & SAS & SSA & \\
\hline AAS & 2.6 & 1.6 & 0.1 & 1.1 & 0.1 & 0.0 & 1.8 & 0.1 & 0.0 & 7.5 \\
EAP & 0.4 & 0.2 & 0.1 & 0.1 & 0.0 & 0.0 & 0.1 & 0.0 & 0.0 & 0.9 \\
ECA & 0.0 & 0.0 & 0.1 & 0.0 & 0.0 & 0.0 & 0.0 & 0.0 & 0.0 & 0.2 \\
EUR & 1.8 & 0.4 & 1.2 & 33.0 & 3.5 & 0.1 & 21.9 & 0.1 & 0.2 & 62.2 \\
LAC & 0.0 & 0.0 & 0.0 & 0.0 & 1.6 & 0.0 & 0.2 & 0.0 & 0.0 & 1.9 \\
MNA & 0.0 & 0.0 & 0.0 & 0.0 & 0.0 & 0.0 & 0.0 & 0.0 & 0.0 & 0.0 \\
NAM & 2.2 & 0.3 & 0.2 & 9.8 & 2.3 & 0.0 & 11.0 & 0.2 & 0.2 & 26.1 \\
SAS & 0.0 & 0.0 & 0.0 & 0.0 & 0.0 & 0.0 & 0.0 & 0.1 & 0.0 & 0.2 \\
SSA & 0.1 & 0.0 & 0.0 & 0.5 & 0.0 & 0.0 & 0.1 & 0.0 & 0.4 & 1.0 \\
\hline & 7.1 & 2.5 & 1.7 & 44.5 & 7.6 & 0.2 & 35.1 & 0.5 & 0.8 & 100 \\
\hline
\end{tabular}

\begin{tabular}{|c|c|c|c|c|c|c|c|c|c|c|}
\hline \multicolumn{4}{|c|}{ Average value 1991 - 1995} & \multicolumn{3}{|c|}{ target } & \multirow[b]{2}{*}{ NAM } & \multirow[b]{2}{*}{ SAS } & \multirow[b]{2}{*}{ SSA } & \\
\hline acquirer & AAS & EAP & ECA & EUR & LAC & MNA & & & & \\
\hline AAS & 3.0 & 0.7 & 0.2 & 1.3 & 0.2 & 0.0 & 3.1 & 0.0 & 0.0 & 8.5 \\
\hline EAP & 0.5 & 0.2 & 0.0 & 1.2 & 0.0 & 0.0 & 0.1 & 0.0 & 0.0 & 2.0 \\
\hline ECA & 0.1 & 0.0 & 0.1 & 0.0 & 0.0 & 0.0 & 0.0 & 0.0 & 0.0 & 0.2 \\
\hline EUR & 2.6 & 0.3 & 1.4 & 34.0 & 1.4 & 0.1 & 15.4 & 0.0 & 0.4 & 55.6 \\
\hline LAC & 0.0 & 0.0 & 0.0 & 0.1 & 0.9 & 0.0 & 0.7 & 0.0 & 0.0 & 1.8 \\
\hline MNA & 0.0 & 0.0 & 0.0 & 0.1 & 0.0 & 0.0 & 0.0 & 0.0 & 0.0 & 0.1 \\
\hline NAM & 2.3 & 0.3 & 0.4 & 12.3 & 2.4 & 0.0 & 12.7 & 0.0 & 0.1 & 30.5 \\
\hline SAS & 0.0 & 0.0 & 0.0 & 0.0 & 0.0 & 0.0 & 0.0 & 0.0 & 0.0 & 0.1 \\
\hline SSA & 0.2 & 0.0 & 0.0 & 0.5 & 0.2 & 0.0 & 0.3 & 0.0 & 0.2 & 1.4 \\
\hline & 8.7 & 1.5 & 2.1 & 49.3 & 5.1 & 0.1 & 32.3 & 0.1 & 0.7 & 100 \\
\hline
\end{tabular}

\begin{tabular}{l|rcccccccc|r}
\multicolumn{1}{l}{$\begin{array}{c}\text { Average value } 1986-1990 \\
\text { acquirer }\end{array}$} & AAS & EAP & ECA & EUR & LAC & MNA & NAM & SAS & SSA & \\
\hline AAS & 2.5 & 0.4 & 0.0 & 4.0 & 0.0 & 0.0 & 9.2 & 0.0 & 0.1 & 16.2 \\
EAP & 0.0 & 0.1 & 0.0 & 0.0 & 0.0 & 0.0 & 0.3 & 0.0 & 0.0 & 0.5 \\
ECA & 0.0 & 0.0 & 0.0 & 0.0 & 0.0 & 0.0 & 0.0 & 0.0 & 0.0 & 0.0 \\
EUR & 1.0 & 0.0 & 0.1 & 19.8 & 1.2 & 0.0 & 26.4 & 0.0 & 0.3 & 48.8 \\
LAC & 0.0 & 0.0 & 0.0 & 0.0 & 0.1 & 0.0 & 0.3 & 0.0 & 0.0 & 0.4 \\
MNA & 0.0 & 0.0 & 0.0 & 0.0 & 0.0 & 0.1 & 0.0 & 0.0 & 0.0 & 0.1 \\
NAM & 1.3 & 0.0 & 0.0 & 6.6 & 0.4 & 0.0 & 24.9 & 0.0 & 0.4 & 33.7 \\
SAS & 0.0 & 0.0 & 0.0 & 0.0 & 0.0 & 0.0 & 0.0 & 0.0 & 0.0 & 0.0 \\
SSA & 0.0 & 0.0 & 0.0 & 0.1 & 0.0 & 0.0 & 0.0 & 0.0 & 0.1 & 0.2 \\
\hline & 4.9 & 0.5 & 0.1 & 30.6 & 1.8 & 0.1 & 61.1 & 0.0 & 0.9 & 100
\end{tabular}

For abbreviations: see Figure 5. 
Most noteworthy in Table 3 is, of course, the large share of European firms buying other European firms, which has been close to one third of the world total since 1990. It seems difficult not to argue that the intra-European M\&A activity has been stimulated by the process of EU integration, the completion of the single market. But if this is the case, the modern FDI models that serve as a benchmark for our chapter have some trouble explaining as they predict that (horizontal) FDI would become less important. One explanation (Barba Navaretti and Venables, 2004, chapter 3) might be that (independently from the level of trade costs) the fixed cost of taking over another European firm has fallen because of the streamlining of national legislation. Table 3 also shows that the share of intra-regional M\&As has been high for AustralAsia and North America (see also below) and that South Asia and the Middle East and North Africa are virtually absent as acquirer and target regions throughout the period.

Table 4 Change in regional distribution of cross-border M\&As; 2001-2005 five year average minus 1986-1990 five year average, rounded to nearest integer

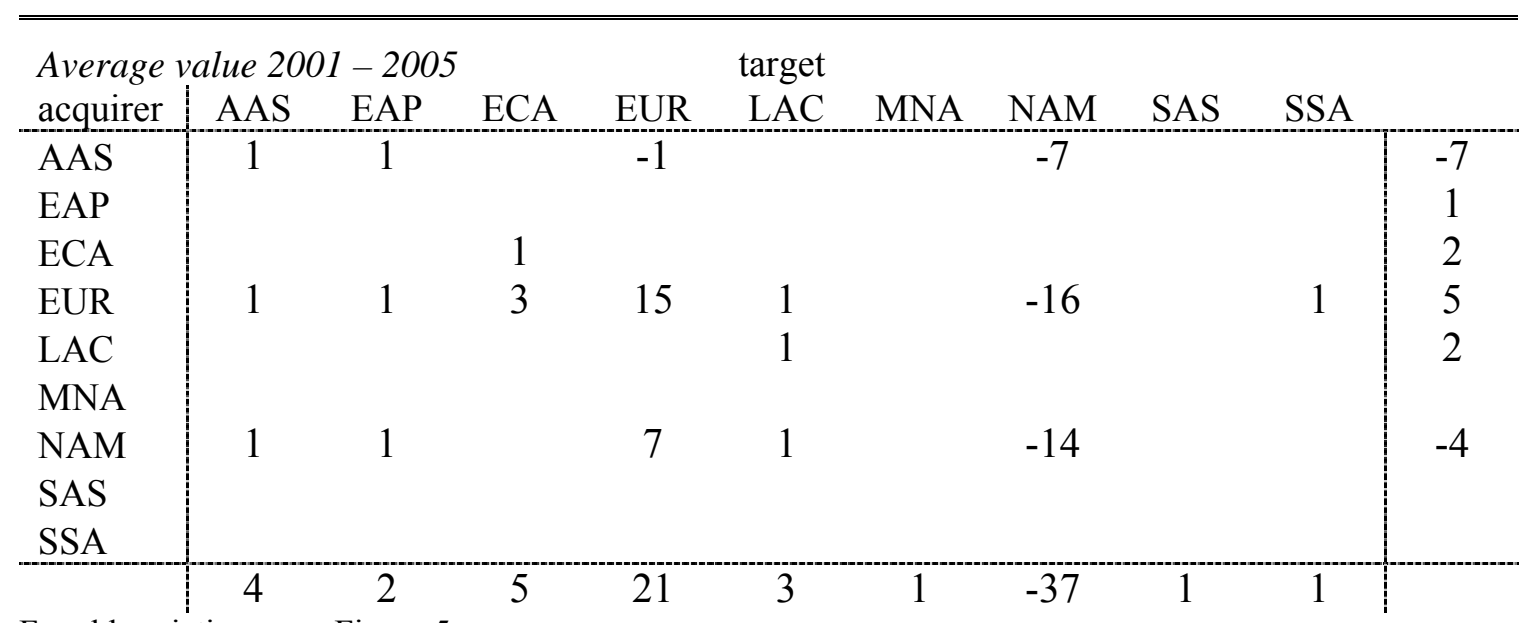

For abbreviations: see Figure 5.

Table 4 highlights the changes in the distribution of cross-border M\&As by subtracting the percentages in the period 1986-1990 from the percentages of the period 2001-2005 and rounding to the nearest integer. AustralAsia and North America have decreased most substantially as acquirer (minus 7 en minus 4 percentage points, respectively), while West and East Europe and Latin America have increased their position (plus 5, 2, and 2 percentage points, respectively). At the expense of North America (minus 37 percentage points) all the other regions have become more important targets, particularly Western and Eastern Europe, AustralAsia, and Latin America (plus 21, 5, 4, and 3 percentage points). The inside of the table shows that 
the most important distributional change has been European firms buying European instead of American firms, and similarly for American firms.

Figure 7 Inter-regional cross-border M\&As; \% of total (value), 2001-2005

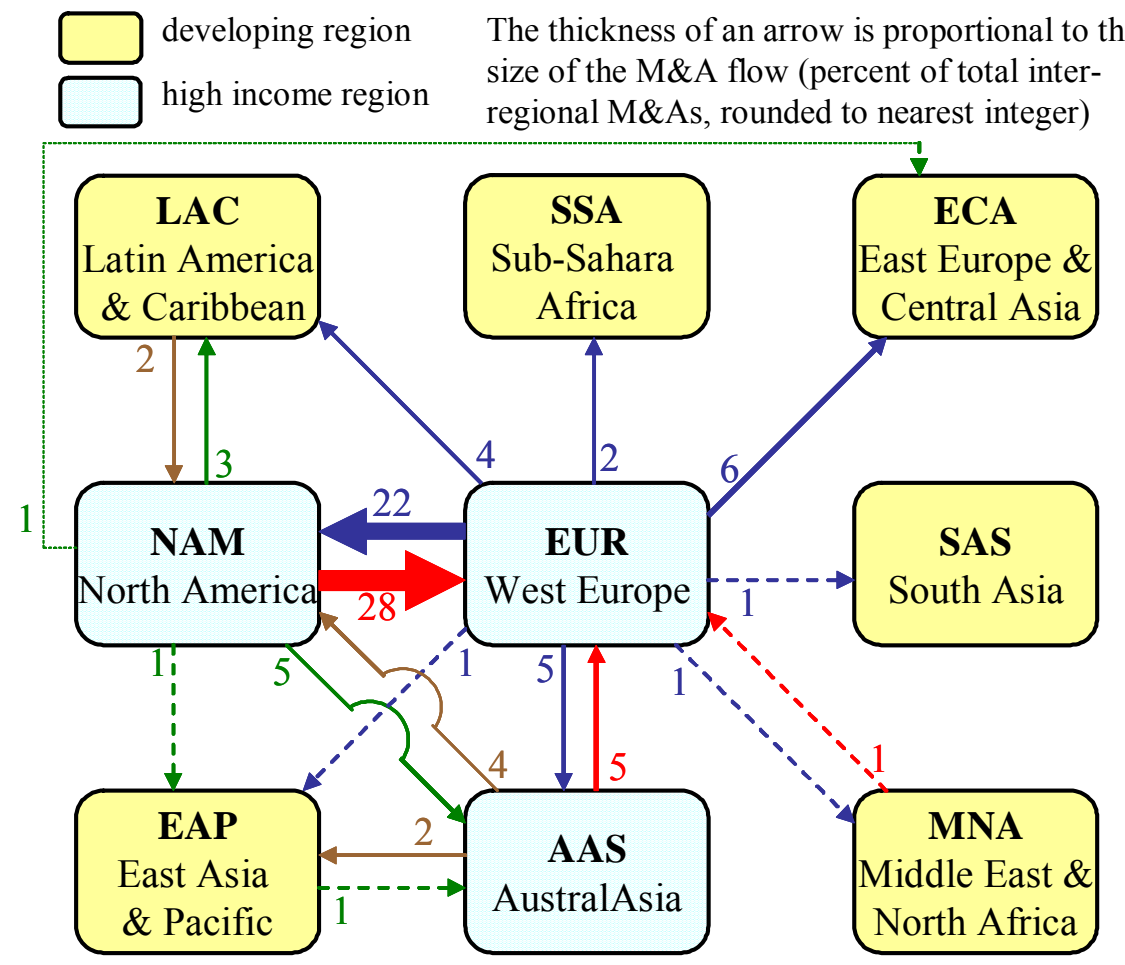

NB: all intra-regional M\&As are excluded from the figure. The total value of inter-regional M\&As is 100 per cent; only flows above 0.5 per cent are shown (this excludes 53 of 72 possible arrows).

Finally, we focus attention on inter-regional M\&As, which gives us an indication of the extent to which different global regions interact with one another. These flows can obviously be (roughly) deduced from Table 3 or the various sub-periods by disregarding the diagonal entries (which sum to about 50 per cent of the total) and readjusting the remaining entries to sum to 100 per cent inter-regional M\&As. Figure 7 graphically depicts the inter-regional cross-border connections for the most recent five-year period (2001-2005), rounded to the nearest integer. Since there are 9 global regions there are 72 different inter-regional connections. Only 19 of these are actually shown in Figure 7 because the remaining 53 are rounded to 0 per cent. First, we note that by far the largest inter-regional M\&As are from North America to Western Europe ( 28 per cent of the total), and vice versa ( 22 per cent of the total). Together these two flows account for 50 per cent of all inter-regional M\&As and clearly dwarf the importance of all other inter-regional connections. Second, we note that Western Europe is substantially buying up firms in Eastern Europe (6 per cent). Third, we note 
that the other connections between the high income regions (between EUR and AAS and between NAM and AAS) are substantial (about 5 per cent each). Fourth, we note that M\&As toward East Asia and the Pacific are still rather small, certainly compared to the attention this receives in the popular media. Fifth, and finally, we note that Western Europe is the only global region with connections to all other regions. This is reminiscent of the dominance of Western Europe in inter-regional trade flows, see van Marrewijk (2007, Ch. 1). So, it seems safe to conclude this section with the observation that indeed most FDI and M\&As take place between the relatively wealthy parts of the world. This observation is in line with our previous findings as to cross border M\&As being mainly of the horizontal type.

\section{$5 \quad$ Countries and M\&As over time}

In view of the high coincidence between acquiring and target countries discussed in sections 3 and 4, it is interesting to make a difference between the largest gross acquirers and targets and the largest net acquirers and targets of M\&As. Looking at net figures corrects for (country) size differences and reveals possible changes in the direction of FDI flows. Since the value and number of cross-border M\&As varies substantially even for the world as a whole, see Figure 3, it should come as no surprise that this variation is even more substantial at the country level, certainly when we look at net M\&A flows. This is illustrated in Figure 8 for the two largest net acquiring countries (UK and France) and net target countries (USA and Brazil) for the period 1985-2005. For the UK, for example, the fluctuations around the average of \$19.1 bn per year range from a low of $-\$ 78$ bn in 2004 to a high of \$295 bn in 1999. For the USA, similarly, the fluctuations around the average of $-\$ 31.3$ bn per year range from a low of $-\$ 205$ bn in 2000 to a high of $\$ 46$ bn in 2003. 
Figure 8 Cross-border M\&As; four largest net acquirers and net targets

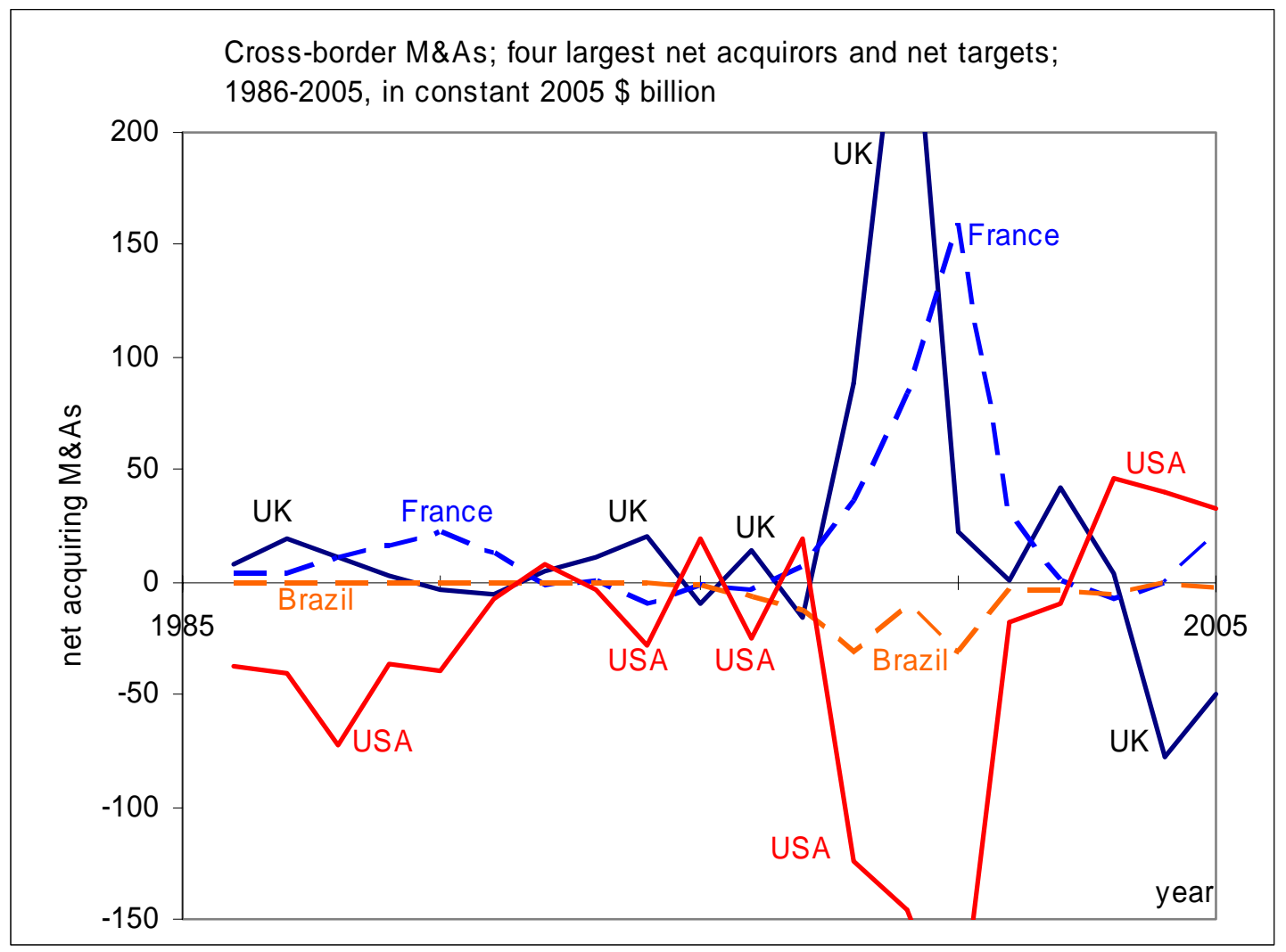

To mitigate the impact of fluctuations over time and to identify important trends over longer time periods, Table 5 lists the most important countries for each of the four categories identified above for the period 1986-2005 as a whole, sub-divided into four five-year sub-periods.

- Table 5a lists the top 10 acquiring countries, consisting of the USA, Canada, Australia, Japan, and six European countries (UK, France, Germany, Netherlands, Switzerland, and Spain). The US and the UK are about equally important in this respect, although the US tops the list in three of the four sub-periods. The role of the Netherlands and Spain as an acquiring nation has become more important in the last 10 years and that of Australia in the last 5 years. In contrast, the role of Japan as an acquiring nation has clearly reduced over time.

- Table 5b lists the top 10 target countries. Except for Italy and Sweden (which replace Switzerland and Japan) it consists of the same countries as Table 5a. The US is undisputedly the largest target country, followed by the UK and Germany. The role of the UK as a target country has clearly increased over time. Similarly, to a lesser extent, has the role of other European countries, particularly in the last five years. 
Table 5 Largest M\&A countries; acquiring and targets, gross and net flows

\begin{tabular}{|c|c|c|c|c|c|c|}
\hline \multirow{2}{*}{\multicolumn{2}{|c|}{$\begin{array}{l}\text { a. Ten largest acquiring } \\
\text { country }\end{array}$}} & \multicolumn{5}{|c|}{ annual average acquiring flows } \\
\hline & & 1986-1990 & 1991-1995 & $1996-2000$ & $2001-2005$ & $1986-2005$ \\
\hline 1 & United States & 41.1 & 42.3 & 142.3 & 118.0 & 85.9 \\
\hline 2 & United Kingdom & 37.2 & 27.0 & 200.3 & 76.7 & 85.3 \\
\hline 3 & France & 17.0 & 13.2 & 85.6 & 34.9 & 37.7 \\
\hline 4 & Germany & 6.4 & 10.7 & 68.7 & 31.5 & 29.3 \\
\hline 5 & Netherlands & 4.3 & 8.1 & 39.8 & 32.8 & 21.2 \\
\hline 6 & Canada & 13.3 & 7.5 & 29.9 & 24.1 & 18.7 \\
\hline 7 & Switzerland & 6.1 & 8.0 & 28.8 & 15.8 & 14.7 \\
\hline 8 & Spain & 2.0 & 2.9 & 27.1 & 24.5 & 14.1 \\
\hline 9 & Australia & 8.2 & 3.7 & 14.1 & 21.4 & 11.9 \\
\hline 10 & Japan & 16.0 & 3.7 & 13.7 & 8.9 & 10.6 \\
\hline
\end{tabular}

b. Ten largest target M\&A countries, 1986-2005 (constant 2005 \$ billion)

\begin{tabular}{ll|cccc:c} 
& & \multicolumn{7}{|c}{ annual average target flows } \\
& country & $1986-1990$ & $1991-1995$ & $1996-2000$ & $2001-2005$ & $1986-2005$ \\
\hline 1 & United States & 86.5 & 44.6 & 238.4 & 99.6 & 117.3 \\
2 & United Kingdom & 29.6 & 22.7 & 119.7 & 92.7 & 66.2 \\
3 & Germany & 4.1 & 7.9 & 83.3 & 40.3 & 33.9 \\
4 & Canada & 11.3 & 6.9 & 37.6 & 22.2 & 19.5 \\
5 & France & 5.8 & 12.9 & 28.9 & 26.1 & 18.4 \\
6 & Netherlands & 3.0 & 5.7 & 29.4 & 20.6 & 14.7 \\
7 & Australia & 4.1 & 8.4 & 18.0 & 13.5 & 11.0 \\
8 & Italy & 3.8 & 5.8 & 10.4 & 21.8 & 10.5 \\
9 & Sweden & 1.7 & 4.9 & 23.7 & 10.3 & 10.2 \\
10 & Spain & 3.1 & 5.0 & 11.1 & 11.8 & 7.8 \\
\hline
\end{tabular}

c. Five largest net acquiring M\&A countries, 1986-2005 (constant 2005 \$ billion) annual average net acquiring flows (acquiring - target)

\begin{tabular}{ll|cccc:c} 
& country & $1986-1990$ & $1991-1995$ & $1996-2000$ & $2001-2005$ & $1986-2005$ \\
\hline 1 & France & 11.3 & 0.3 & 56.8 & 8.8 & 19.3 \\
2 & United Kingdom & 7.6 & 4.3 & 80.6 & -16.0 & 19.1 \\
3 & Switzerland & 3.5 & 5.5 & 20.3 & 8.0 & 9.3 \\
4 & Netherlands & 1.3 & 2.4 & 10.3 & 12.3 & 6.6 \\
5 & Spain & -1.1 & -2.1 & 16.0 & 12.7 & 6.4 \\
\hline
\end{tabular}

d. Five largest net target M\&A countries, 1986-2005 (constant 2005 \$ billion)

annual average net target flows (target - acquiring)

\begin{tabular}{ll|cccc:c} 
& country & $1986-1990$ & $1991-1995$ & $1996-2000$ & $2001-2005$ & $1986-2005$ \\
\hline 1 & United States & 45.4 & 2.3 & 96.1 & -18.4 & 31.3 \\
2 & Brazil & 0.2 & 0.6 & 18.6 & 2.8 & 5.6 \\
3 & Germany & -2.4 & -2.7 & 14.5 & 8.8 & 4.6 \\
4 & China & 0.0 & 0.2 & 11.4 & 5.3 & 4.2 \\
5 & Argentina & 1.8 & 1.3 & 11.0 & 1.8 & 4.0
\end{tabular}

- Table 5c lists the top 5 net acquiring countries, consisting of five European countries: France, UK, Switzerland, the Netherlands, and Spain. Of these five, 
Switzerland and the Netherlands have been stable net acquiring countries throughout the time period, whereas the net position of France has been more volatile. The UK's net position recently switched from acquiring to target, and vice versa for Spain.

- Finally and most interestingly from the globalization debate perspective, Table $5 \mathrm{~d}$ lists the top 5 net target countries, consisting of the US, Brazil, Germany, China, and Argentina. Of these five, Brazil and Argentina have been stable net target countries throughout the period, whereas China, like Germany, became an important net target in the last 10 years only. The US has been a primary net target most of the time, switching roles with the UK only in the last five years. The analysis reveals that despite the dominant position of the US, recently high income countries are turning towards emerging markets, of which China stands out as the most recent net target. Folk wisdom about the increasing importance of China - and other promising markets - thus seems correct in this respect. This also implies a challenge for FDI modeling. Typically, see Barba Navaretti and Venables (2004, chapter 3), when the possibility of M\&A as an FDI option is taken into account this is in models of horizontal FDI, which given the facts we have presented so far, should not come as a surprise. But, the information provided by Table $5 \mathrm{~d}$ suggests that (increasingly?) cross border M\&A is also aimed at low(er) income countries where the market seeking aspect is probably far less relevant than the (labor) cost saving argument. This means that cross border M\&A should be part of models of vertical FDI as well. It might be that cross border M\&As become an increasingly viable alternative for Greenfield FDI or outright outsourcing in view of the well-known asymmetric information problems (the hold up problem) associated with the FDI-versus-outsourcing decision.

\section{Inequality between cross-border M\&As}

One of the reasons for the attention for the M\&A phenomenon in- and certainly outside academia is undoubtedly the sense of involvement of national pride in M\&A deals (either positively or negatively). Another, perhaps even more important, reason for this attention is the size of some of the cross-border M\&A. Indeed, some of the deals are so large that they can have a substantial influence on a country's position as a (net) acquirer or target. Table 6 lists the largest deals by year of announcement, valued in current and constant dollars, as well as the two countries that are involved. Several conclusions can be drawn from this table. First, there is substantial variation in the maximum value over time (a 50-fold difference between the highest and lowest 
value). Second, a single deal can indeed have a substantial influence. The Vodafone takeover of Mannesmann already mentioned in section 2 is by far the largest M\&A. It has also clearly influenced the net acquiring position of the UK and the net target position of Germany. Third, the USA is by far the most popular target country for these mega deals (12 out of 20 observations), while Europe is the most popular acquiring region (13 out of 20 observations). Fourth, and finally, even when measured in constant dollars, there seems to be a tendency for the maximum value to increase over time. ${ }^{2}$ This has led to the suggestion in the literature that the size distribution of M\&As has become more unequal over time (Evenett, 2004). This section analyzes that suggestion in more detail.

Table 6 Value of largest cross-border M\&As (announced year)

\begin{tabular}{|c|c|c|c|c|c|c|}
\hline \multirow[b]{2}{*}{ year } & \multicolumn{2}{|c|}{$\begin{array}{r}\text { value of deal (bn.) } \\
\text { constant }\end{array}$} & \multicolumn{4}{|c|}{ Firm and country information } \\
\hline & current $\$$ & $2005 \$$ & firm & country & firm & country \\
\hline 1986 & 3.6 & 5.6 & Campeau & Canada & Allied Stores & USA \\
\hline 1987 & 7.9 & 12.0 & BP America & USA & Standard Oil & USA \\
\hline 1988 & 6.5 & 9.7 & Campeau & Canada & Fed Dep St. & USA \\
\hline 1989 & 7.9 & 11.4 & Beecham & UK & Smith Kline & USA \\
\hline 1990 & 7.4 & 10.3 & Matsuhita E & Japan & MCA & USA \\
\hline 1991 & 3.3 & 4.3 & Altus Fin. & France & Ex. Life & USA \\
\hline 1992 & 4.6 & 6.0 & Reed & UK & Elsevier & Netherl. \\
\hline 1993 & 6.3 & 8.0 & Metro etc. & Malaysia & ASKO etc. & Germany \\
\hline 1994 & 5.3 & 6.5 & Roche & Switzerl. & Syntex & USA \\
\hline 1995 & 7.3 & 8.8 & Hoechst & Germany & Marion etc. & USA \\
\hline 1996 & 4.2 & 5.0 & Fresenius & Germany & Nat Med ca & USA \\
\hline 1997 & 17.1 & 19.8 & Zürich Vers & Switzerl. & BAT Ind & UK \\
\hline 1998 & 48.2 & 54.9 & BP & UK & Amoco & USA \\
\hline 1999 & 202.8 & 228.7 & Vodafone & UK & Mannesman & Germany \\
\hline 2000 & 46.0 & 51.1 & France Tel & France & Orange & UK \\
\hline 2001 & 12.8 & 14.0 & Citigroup & USA & Banacci & Mexico \\
\hline 2002 & 15.3 & 16.2 & HSBC & UK & Household I & USA \\
\hline 2003 & 11.1 & 11.6 & Manulife & Canada & J Hancock & USA \\
\hline 2004 & 74.6 & 76.5 & R D Petrol & Netherl. & Shell Transp & UK \\
\hline 2005 & 31.7 & 31.7 & Telefonica & Spain & $\mathrm{O} 2$ & UK \\
\hline
\end{tabular}

\footnotetext{
${ }^{2}$ A trendline of the logarithm of the maximum value in the period 1985-2005 explains about half of the variance and suggests a rate of increase at 0.13 per cent per year.
} 
Figure 9 Lorenz curves of cross-border M\&As, selected years

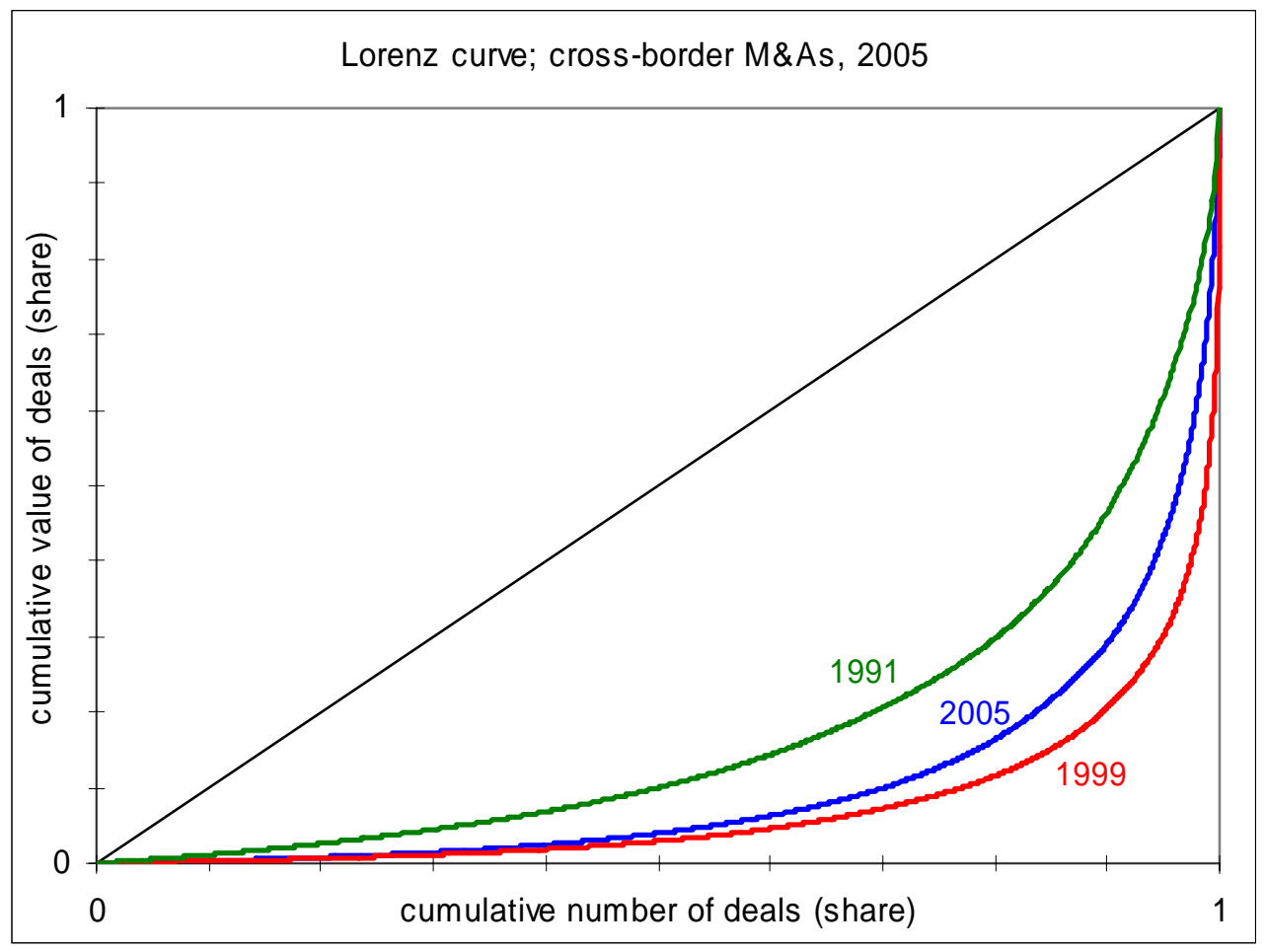

A proper understanding of the degree of inequality of a distribution must, of course, take all observations into consideration, rather than focusing just on the maximum value. An excellent, and popular, method is to construct Lorenz curves, where the observations are ordered in increasing value, with the share of the cumulative number of deals on the horizontal axis and the share of the cumulative value of these deals on the vertical axis. Figure 9 provides examples of these curves in the years 1991, 1999, and 2005. If all the observations in a particular year had an equal value, the Lorenz curve would coincide with the diagonal. The area below the diagonal and above the curve (times two) therefore provides a measure of the inequality of the observations, a number between 0 (complete equality) and 1 (complete inequality) known as the Gini coefficient. We calculated the Gini coefficient for each year of our data set. 
Figure 10 Cross-border M\&As, 1985-2005; Gini coefficients and value

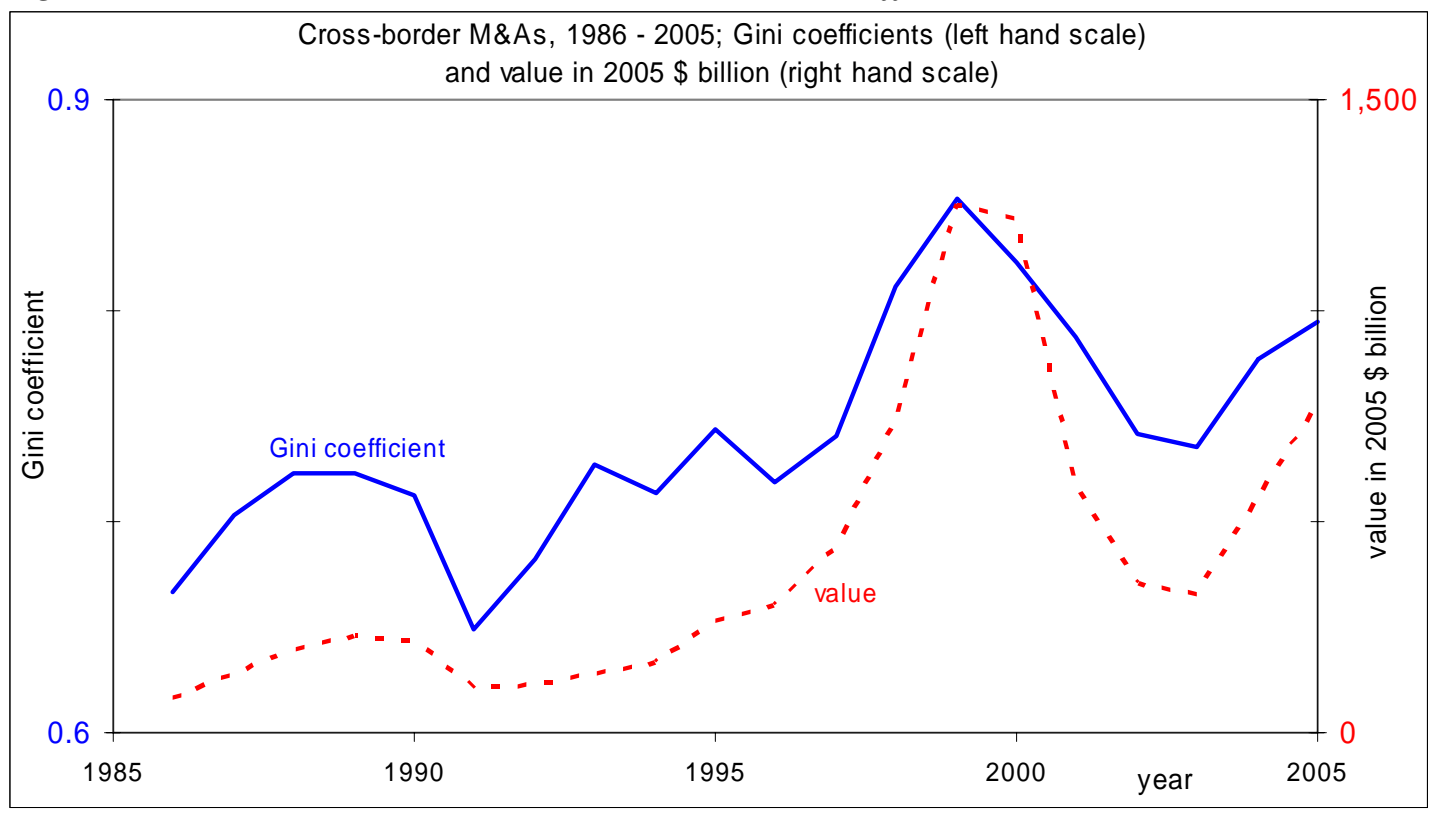

Figure 10 provides an overview of the evolution of the Gini coefficient over time for the period 1986-2005. There is, indeed, a tendency of the Gini coefficient to increase over time, supporting the suggestion that the degree of inequality in cross-border M\&As increases over time. ${ }^{3}$ The variation from year to year is substantial, however, ranging from a low of 0.649 in 1991 to a high of 0.853 in 1999 , see also the associated Lorenz curves in Figure 9. More importantly, by including the evolution over time of the total value of cross-border M\&As in the same diagram, Figure 10 draws attention to the relationship between inequality as measured by the Gini coefficient and the wave phenomenon. Clearly, the Gini coefficient increases during the $4^{\text {th }}$ wave of the late 1980s, then declines after this peak has been reached, to increase again during the $5^{\text {th }}$ wave of the late $1990 \mathrm{~s}$, to decline again after the absolute peak in 1999, and starts to increase again during the $6^{\text {th }}$ wave starting in 2003.

\footnotetext{
${ }^{3}$ A trendline of the Gini coefficient explains almost half of the variance and suggests an increase in the Gini value at a rate of about 0.0061 per year.
} 
Figure 11 Relative changes in value of M\&As and Gini coefficient, 1986-2005

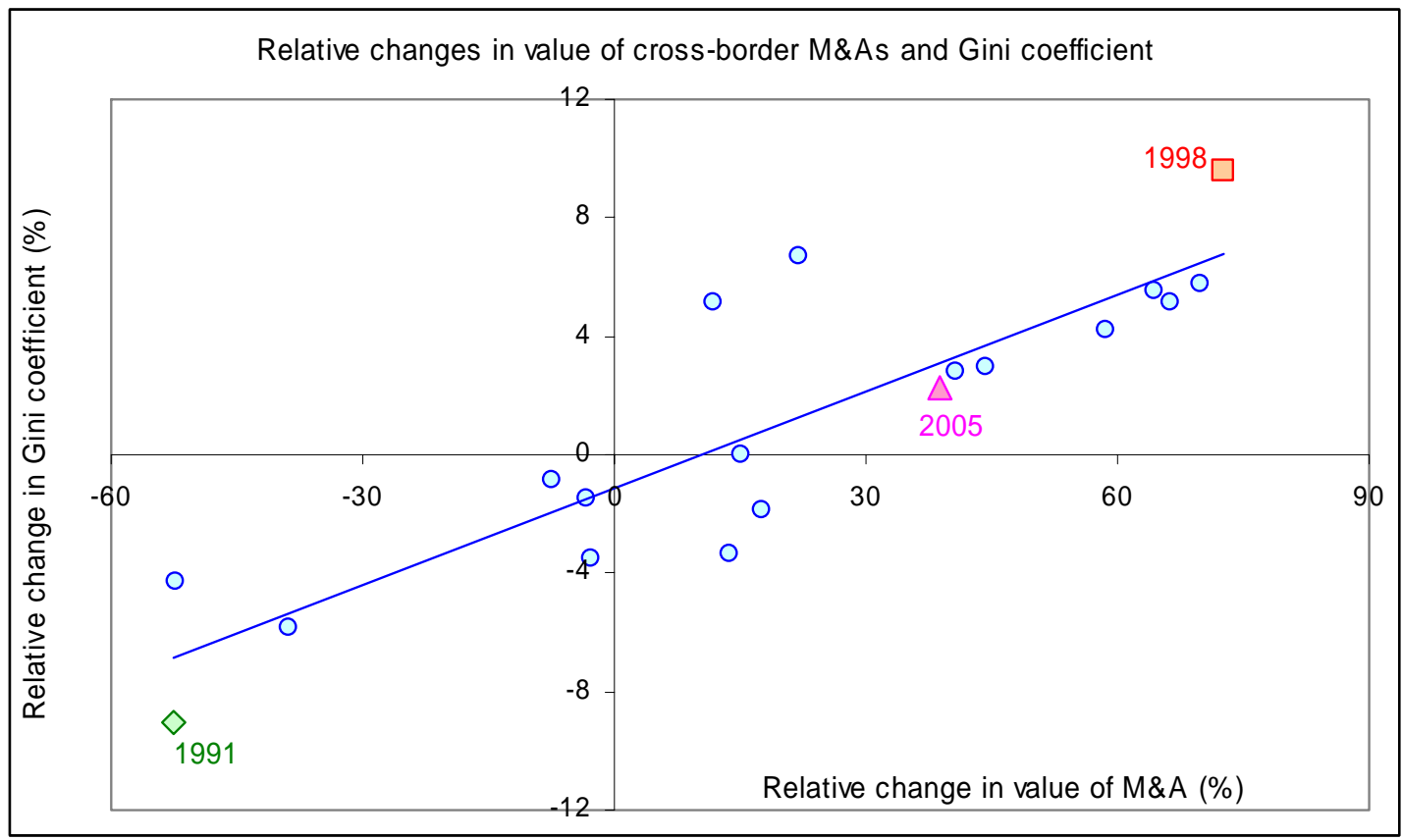

Figure 11 illustrates the coincidence of changes in inequality, measured by the relative change in the Gini coefficient, and merger waves, measured by the relative change in the value of cross-border M\&As. There is a clear positive relationship between these two phenomena. If we let $G I_{t}$ be the Gini coefficient in year $t, V_{t}$ the value of crossborder M\&As (in constant $2005 \$$ bn), and let $\sim$ denote a relative change, that is $\widetilde{x}_{t} \equiv\left(x_{t}-x_{t-1}\right) / x_{t-1}$ for $x_{t}=G I_{t}, V_{t}$, then we get (t-values in parentheses):

$$
\widetilde{G} I_{t} \approx-\underset{(-1.76)}{1.1207}+\underset{(7.38)}{0.1085} \cdot \widetilde{V}_{t} ; \quad \bar{R}^{2}=0.75
$$

A one per cent increase in the value of cross-border M\&As therefore causes about a 0.1 per cent increase in the Gini coefficient. The gradual increase in the real value of cross-border M\&As over time is therefore probably largely responsible for the observed increase in inequality. ${ }^{4}$ This begs the question what causes the increase in the value of the M\&As during the 1990s. The most important reason is that regulations with respect to M\&A have changed over time. Especially the financial service sector, banking sector, (tele)communication sector, and media firms have been allowed to merge with or acquire 'over-seas' firms (Evenett, 2004, Muelfeld et al., 2007). Once the regulations became more relaxed, the local 'giants' were looking for profitable M\&A. Does this make sense from the perspective of the modern FDI

\footnotetext{
${ }^{4}$ It should be noted, moreover, that changes in the maximum M\&A value are only weakly (positively) correlated with changes in the Gini coefficient.
} 
theories that play such a dominant role in the current research in international economics? To start with, the idea of merger waves can be explained as equation (1) already suggests that once the initial mergers have taken place and competition is reduced it becomes profitable for other firms to also become engaged in the M\&A activity, but the problem is how to explain the initial mergers. The association of the merger wave, with a strong European flavor, with changes in regulation can be aligned with theoretical models of (horizontal) FDI as long as this is looked upon as a decrease in the organizational costs of setting up and arranging a M\&A. If these costs are to be looked upon as a fall in trade costs and thus as a manifestation of increased economic integration these models are thus, as we have argued before, not very well equipped to explain the data in Figure 10. May be, the limits of existing FDI models with more or less all build on equation (1) come to the fore here and to understand what is driving merger waves we might look at alternative theories like the managerial hubris theory (Roll, 1986). Managers tend to err positively when it comes to the valuation of targets, and thus tend to overpay. Especially during the hay day of the dotcom bubble in the late 1990s this could explain the increase in value of the M\&As. Although managerial hubris is not part of our categorization scheme from box 1 , it points to the fact that M\&A are facilitated in the upswings of business cycles.

\section{$7 \quad$ Looking more closely at individual firms that engage in M\&A}

Until now we have not discussed individual firms. ${ }^{5}$ In this section we briefly discuss the main insight that results from the research on FDI and firm heterogeneity namely that within a sector there is considerable firm heterogeneity to the effect that only the most productive firms are expected to be engaged in FDI and thus in cross-border M\&A (as an acquiring firm). The idea that firms from the same sector differ (a lot) is probably not a path breaking observation, but for the fact that there is a systematic relation between plant productivity and the mode of entry in international trade. Bernard et al. (2003) show that a systematic relation exists between productivity and whether or not firms are engaged in exports. They show that of 200.000 (US-) firms in their sample only 21 percent report any export. Less than 5 per cent of these firms export more than 50 per cent, which shows that even if firms are engaged in

\footnotetext{
${ }^{5}$ The Thomson data do not allow us to calculate the productivity measures as used by Bernard et al. (2003) or differentiate between domestic sales exports or FDI at the plant level. In this section we review some of the relevant literature that has original plant level data on productivity.
} 
international trade, most are still most active in domestic markets - two-thirds of the exporters export less than 10 per cent of their output. Most interestingly, those that export have higher productivity levels, and thus are able to charge a higher mark-up. Given the fact that international trade is more costly than domestic sales, only productive firms are able to cover trade costs. Despite these trade costs they can still be competitive in foreign markets, just because they are efficient. So, export reveals high productive plants.

Helpman et al. (2004) take this line of reasoning one step further by not only looking at the export decision, but by also taking the FDI decision into account. Because FDI is even more expensive than exports, only the most efficient firms are able to engage in FDI. They find strong evidence for a sample of US and European firms that only the most productive firms are engaged in FDI. Studies like these confirm the notion that transportation costs are not only important to describe international trade patterns, but also FDI flows. We report these results because they also explain why most FDI is between rich countries (see sections 3 and 4). Instead of emphasizing market-seeking arguments, the firm heterogeneity argument points out that most FDI and thus cross border M\&A is between rich countries because that is where the most productive firms are located. Our data set, the Thomson data set on M\&A, does not allow for an easy differentiation of firms in terms of productivity, but additional stylized facts on the productivity of firms engaged in cross border M\&A could help to establish if this new firm heterogeneity literature makes sense when applied to M\&A. We leave this for future research.

\section{Summary and Conclusions}

The well-known advice of Leamer and Levinsohn (1995) to "estimate, don't test", implies that, given the current state of the theories and the quality of the data, the Popperian test of falsifying a theory is hardly possible (ibid, p. 1314): "we may statistically "reject" the theory, but leave it completely unharmed nonetheless. After all, we already knew it wasn't literally true." What empirical work should be doing, according to them, is (ibid, p. 1342): "not to test the validity of the theory but to determine if the theory is working adequately in its limited domain." So, in practice the distinction between verifying or falsifying theories is less clear-cut than one would ideally want. This boils down to ask theorists to think about the link between theory and observable 
phenomena. The aim of this chapter is to present the correlations in the data on cross border M\&As, and ask the theorists to develop useful models that give us some understanding about the underlying causation. Our chapter provides guidelines for theory on an very important phenomenon, cross-border M\&As, as to what the most important correlations might be. Using the well-known Thomson data set, we show that cross-border mergers and acquisitions (M\&As) have a number of features:

- most FDI is in the form of cross-border M\&As,

- firms engaged in cross-border M\&As seem to be 'market-seeking',

- cross-border M\&As come in waves (the most recent wave is still unfolding),

- economic integration (international deregulation) stimulated M\&As,

- the size of and inequality between M\&As grows (over time).

Our contention in this chapter is that these stylized facts drive and should drive theoretical contributions from international economics that try to understand crossborder M\&As. A number of recent models that are firmly rooted in the $1^{\text {st }}$ principles of trade theory, see Neary (2003), go a long way in explaining some of these facts. What is still missing, given our stylized facts, is a full-fledged model of M\&As. It might of course be that tools of modern international economics do not allow for such an all encompassing theory but ongoing research by economists like Neary, Helpman or Mélitz suggests that our understanding of cross-border M\&As will improve in the near future. This is real progress, because from the perspective of mainstream international economics, cross-border M\&As has too long been a case of interesting facts in search of a theory. 


\section{References}

Andrade, G., M. Mitchell, and E. Stafford (2001), "New evidence and perspectives on mergers," Journal of Economic Perspectives, 15(2): 103-120.

Barba Navaretti, G., and A.J. Venables (2004), Multinational firms in the world economy, Princeton University Press, Princeton, N.J.

Bernard, A.B., J. Eaton, J.B. Jensen, and S. Kortum (2003), "Plants and productivity in international trade," American Economic Review, 93: 1268-1290.

Brakman, S., H. Garretsen, and C. van Marrewijk (2005), "Cross-border mergers and acquisitions: on revealed comparative advantage and merger waves," CESifo Working Paper No. 1602.

Brakman, S., H. Garretsen, and C. van Marrewijk (2006), “Comparative advantage, cross-border mergers, and merger waves: international economics meets industrial organization," CESifo Forum (1): 22-26.

Brakman, S., H. Garretsen, C. van Marrewijk, and A Van Witteloostuijn (2006), Nations and Firms in the Global Economy, Cambridge University Press, Cambridge, U.K.

Dunning, J.H. (1993), Multinational Enterprises and the Global Economy, AddisonWesley, Wokingham.

Evenett, S.J. (2004), “The cross border mergers and acquisitions wave of the late 1990s,” in: R.E. Baldwin and L.A. Winters (eds.), Challenges to Globalization, University of Chicago Press, Chicago.

Fridolfsson, S.-O., and J. Stennek (2005), "Why mergers reduce profits and raise share prices - a theory of preemptive mergers," Journal of the European Economic Association 3(5): 1083-1104.

Gugler, K., D.C. Mueller, B.B. Yurtoglu, and C. Zulehner (2003), "The effects of mergers: an international comparison," International Journal of Industrial Organization 21: 625-653.

Helpman, E., M.J. Melitz, and S.R. Yeaple, "Exports versus FDI with Heterogeneous Firms," American Economic Review, Vol. 94, pp. 300-316.

Helpman, E. (2006), “Trade, FDI, and the organization of firms," NBER Working paper, No. 12091, Cambridge.

Leamer, E.E., and J. Levinsohn (1995), “International trade theory: the evidence,” in:

G.M. Grossman and K. Rogoff (eds.), Handbook of International Economics, Vol.3, North-Holland, Amsterdam. 
Marrewijk, C. van (2002), International trade and the world economy, Oxford University Press, Oxford, U.K.

Marrewijk, C. van (2007), International economics: theory, application, and policy, Oxford University Press, Oxford, U.K.

Muelfeld, K., P.R. Sahib, and A. van Witteloostuijn (2007), "Completion or abandonment of mergers and acquisitions: evidence from the newspaper industry, 1981-2000," Journal of Media Economics, Forthcoming.

Neary, J.P. (2003), “Globalization and market structure," Journal of the European Economic Association 1: 245-271.

Neary, J.P. (2004a), "Cross-border mergers as instruments of comparative advantage," mimeo, Dublin.

Neary, J.P. (2004b), "Monopolistic competition and international trade theory," in: S. Brakman and B.J. Heijdra (eds.), The monopolistic competition revolution in retrospect, Cambridge University Press, Cambridge, U.K.

Neary, J.P. (2005) "Trade costs and foreign direct investment," presented to the CESifo Summer Institute Workshop on Recent Developments on International Trade: Globalization and the Multinational Enterprise, Venice, July 2005.

Roll, R.(1986), "The hubris hypothesis of corporate takeovers," Journal of Business, 59: 197-216.

UNCTAD, 2000, World Investment Report, Geneva, Switzerland. 


\section{Appendix Global regions}

Table A1 Global regions: country composition

\begin{tabular}{lll} 
EAP _ East Asia and Pacific; 27 developing countries & \\
\hline American Samoa & Marshall Islands & Samoa \\
Cambodia & Micronesia & Solomon Islands \\
China & Mongolia & Taiwan \\
Fiji & Myanmar & Thailand \\
Indonesia & Nauru & Timor, East \\
Kiribati & N. Mariana Islands & Tonga \\
Korea, North & Palau & Tuvalu \\
Laos & Papua New Guinea & Vanuatu \\
Malaysia & Philippines & Vietnam
\end{tabular}

ECA - Europe and Central Asia; 28 developing countries

\begin{tabular}{lll} 
Albania & Hungary & Russia \\
Armenia & Kazakhstan & Serbia and Montenegro \\
Azerbaijan & Kyrgyz Republic & Slovak Republic \\
Belarus & Latvia & Tajikistan \\
Bosnia-Herzegovina & Lithuania & Turkey \\
Bulgaria & Macedonia & Turkmenistan \\
Croatia & Moldova & Ukraine \\
Czech Republic & Poland & Uzbekistan \\
Estonia & Romania & Yugoslavia \\
Georgia & & \\
\hline
\end{tabular}

LAC - Latin America and the Caribbean; 33 developing countries

\begin{tabular}{lll}
\hline Argentina & Ecuador & Nicaragua \\
Barbados & El Salvador & Panama \\
Belize & French Guiana & Paraguay \\
Bolivia & Grenada & Peru \\
Brazil & Guatemala & St Kitts and Nevis \\
Chile & Guyana & St Lucia \\
Colombia & Haiti & St Vincent \& Grenadines \\
Costa Rica & Honduras & Suriname \\
Cuba & Jamaica & Trinidad And Tobago \\
Dominica & Martinique & Uruguay \\
Dominican Republic & Mexico & Venezuela \\
\hline
\end{tabular}

MNA - Middle East and North Africa; 14 developing countries

\begin{tabular}{lll} 
Algeria & Jordan & Syria \\
Djibouti & Lebanon & Tunisia \\
Egypt & Libya & West Bank \\
Iran & Morocco & Yemen \\
Iraq & Oman & \\
\hline
\end{tabular}

SAS - South Asia; 8 developing countries

$\begin{array}{lll}\text { Afghanistan } & \text { India } & \text { Pakistan } \\ \text { Bangladesh } & \text { Maldives } & \text { Sri Lanka } \\ \text { Bhutan } & \text { Nepal } & \end{array}$


Table A1 continued

\begin{tabular}{lll}
\hline SSA - Sub Sahara Africa; 48 developing countries & \\
\hline Angola & Gabon & Niger \\
Benin & Gambia & Nigeria \\
Botswana & Ghana & Rwanda \\
Burkina Faso & Guinea & Sao Tome And Principe \\
Burundi & Guinea-Bissau & Senegal \\
Cameroon & Kenya & Seychelles \\
Cape Verde & Lesotho & Sierra Leone \\
Central African Republic & Liberia & Somalia \\
Chad & Madagascar & South Africa \\
Comoros & Malawi & Sudan \\
Congo & Mali & Swaziland \\
Congo, Dem Rep (Zaire) & Mauritania & Tanzania \\
Cote D'ivoire & Mauritius & Togo \\
Equatorial Guinea & Mayotte & Uganda \\
Eritrea & Mozambique & Zambia \\
Ethiopia & Namibia & Zimbabwe \\
\hline
\end{tabular}

\begin{tabular}{lll} 
AAS - Australasia; 8 high income countries & \\
\hline Australia & Japan & New Zealand \\
Brunei & Korea, South & Singapore \\
Hong Kong & Macao & \\
\hline
\end{tabular}

EUR - Western Europe; 36 high income countries

\begin{tabular}{lll}
\hline Andorra & Greenland & New Caledonia \\
Austria & Iceland & Norway \\
Bahrain & Ireland & Portugal \\
Belgium & Isle Of Man & Qatar \\
Channel Islands & Israel & San Marino \\
Cyprus & Italy & Saudi Arabia \\
Denmark & Kuwait & Slovenia \\
Faeroe Islands & Liechtenstein & Spain \\
Finland & Luxembourg & Sweden \\
France & Malta & Switzerland \\
Germany & Monaco & United Arab Emirates \\
Greece & Netherlands & United Kingdom \\
\hline
\end{tabular}

NAM - North America; 11 high income countries

$\begin{array}{lll}\text { Antigua and Barbuda } & \text { Canada } & \text { Puerto Rico } \\ \text { Bahamas } & \text { Cayman Islands } & \text { United States } \\ \text { Bermuda } & \text { Guam } & \text { Virgin Islands (Us) } \\ & \text { Neth. Antilles } & \end{array}$




\section{CESifo Working Paper Series}

(for full list see www.cesifo-group.de)

1760 Pascalis Raimondos-Møller and Alan D. Woodland, Steepest Ascent Tariff Reforms, July 2006

1761 Ronald MacDonald and Cezary Wojcik, Catching-up, Inflation Differentials and Credit Booms in a Heterogeneous Monetary Union: Some Implications for EMU and new EU Member States, July 2006

1762 Robert Dur, Status-Seeking in Criminal Subcultures and the Double Dividend of ZeroTolerance, July 2006

1763 Christa Hainz, Business Groups in Emerging Markets - Financial Control and Sequential Investment, July 2006

1764 Didier Laussel and Raymond Riezman, Fixed Transport Costs and International Trade, July 2006

1765 Rafael Lalive, How do Extended Benefits Affect Unemployment Duration? A Regression Discontinuity Approach, July 2006

1766 Eric Hillebrand, Gunther Schnabl and Yasemin Ulu, Japanese Foreign Exchange Intervention and the Yen/Dollar Exchange Rate: A Simultaneous Equations Approach Using Realized Volatility, July 2006

1767 Carsten Hefeker, EMU Enlargement, Policy Uncertainty and Economic Reforms, July 2006

1768 Giovanni Facchini and Anna Maria Mayda, Individual Attitudes towards Immigrants: Welfare-State Determinants across Countries, July 2006

1769 Maarten Bosker and Harry Garretsen, Geography Rules Too! Economic Development and the Geography of Institutions, July 2006

1770 M. Hashem Pesaran and Allan Timmermann, Testing Dependence among Serially Correlated Multi-category Variables, July 2006

1771 Juergen von Hagen and Haiping Zhang, Financial Liberalization in a Small Open Economy, August 2006

1772 Alessandro Cigno, Is there a Social Security Tax Wedge?, August 2006

1773 Peter Egger, Simon Loretz, Michael Pfaffermayr and Hannes Winner, Corporate Taxation and Multinational Activity, August 2006

1774 Jeremy S.S. Edwards, Wolfgang Eggert and Alfons J. Weichenrieder, The Measurement of Firm Ownership and its Effect on Managerial Pay, August 2006 
1775 Scott Alan Carson and Thomas N. Maloney, Living Standards in Black and White: Evidence from the Heights of Ohio Prison Inmates, 1829 - 1913, August 2006

1776 Richard Schmidtke, Two-Sided Markets with Pecuniary and Participation Externalities, August 2006

1777 Ben J. Heijdra and Jenny E. Ligthart, The Transitional Dynamics of Fiscal Policy in Small Open Economies, August 2006

1778 Jay Pil Choi, How Reasonable is the 'Reasonable' Royalty Rate? Damage Rules and Probabilistic Intellectual Property Rights, August 2006

1779 Ludger Woessmann, Efficiency and Equity of European Education and Training Policies, August 2006

1780 Gregory Ponthiere, Growth, Longevity and Public Policy, August 2006

1781 Laszlo Goerke, Corporate and Personal Income Tax Declarations, August 2006

1782 Florian Englmaier, Pablo Guillén, Loreto Llorente, Sander Onderstal and Rupert Sausgruber, The Chopstick Auction: A Study of the Exposure Problem in Multi-Unit Auctions, August 2006

1783 Adam S. Posen and Daniel Popov Gould, Has EMU had any Impact on the Degree of Wage Restraint?, August 2006

1784 Paolo M. Panteghini, A Simple Explanation for the Unfavorable Tax Treatment of Investment Costs, August 2006

1785 Alan J. Auerbach, Why have Corporate Tax Revenues Declined? Another Look, August 2006

1786 Hideshi Itoh and Hodaka Morita, Formal Contracts, Relational Contracts, and the Holdup Problem, August 2006

1787 Rafael Lalive and Alejandra Cattaneo, Social Interactions and Schooling Decisions, August 2006

1788 George Kapetanios, M. Hashem Pesaran and Takashi Yamagata, Panels with Nonstationary Multifactor Error Structures, August 2006

1789 Torben M. Andersen, Increasing Longevity and Social Security Reforms, August 2006

1790 John Whalley, Recent Regional Agreements: Why so many, why so much Variance in Form, why Coming so fast, and where are they Headed?, August 2006

1791 Sebastian G. Kessing and Kai A. Konrad, Time Consistency and Bureaucratic Budget Competition, August 2006 
1792 Bertil Holmlund, Qian Liu and Oskar Nordström Skans, Mind the Gap? Estimating the Effects of Postponing Higher Education, August 2006

1793 Peter Birch Sørensen, Can Capital Income Taxes Survive? And Should They?, August 2006

1794 Michael Kosfeld, Akira Okada and Arno Riedl, Institution Formation in Public Goods Games, September 2006

1795 Marcel Gérard, Reforming the Taxation of Multijurisdictional Enterprises in Europe, a Tentative Appraisal, September 2006

1796 Louis Eeckhoudt, Béatrice Rey and Harris Schlesinger, A Good Sign for Multivariate Risk Taking, September 2006

1797 Dominique M. Gross and Nicolas Schmitt, Why do Low- and High-Skill Workers Migrate? Flow Evidence from France, September 2006

1798 Dan Bernhardt, Stefan Krasa and Mattias Polborn, Political Polarization and the Electoral Effects of Media Bias, September 2006

1799 Pierre Pestieau and Motohiro Sato, Estate Taxation with Both Accidental and Planned Bequests, September 2006

1800 Øystein Foros and Hans Jarle Kind, Do Slotting Allowances Harm Retail Competition?, September 2006

1801 Tobias Lindhe and Jan Södersten, The Equity Trap, the Cost of Capital and the Firm's Growth Path, September 2006

1802 Wolfgang Buchholz, Richard Cornes and Wolfgang Peters, Existence, Uniqueness and Some Comparative Statics for Ratio- and Lindahl Equilibria: New Wine in Old Bottles, September 2006

1803 Jan Schnellenbach, Lars P. Feld and Christoph Schaltegger, The Impact of Referendums on the Centralisation of Public Goods Provision: A Political Economy Approach, September 2006

1804 David-Jan Jansen and Jakob de Haan, Does ECB Communication Help in Predicting its Interest Rate Decisions?, September 2006

1805 Jerome L. Stein, United States Current Account Deficits: A Stochastic Optimal Control Analysis, September 2006

1806 Friedrich Schneider, Shadow Economies and Corruption all over the World: What do we really Know?, September 2006

1807 Joerg Lingens and Klaus Waelde, Pareto-Improving Unemployment Policies, September 2006 
1808 Axel Dreher, Jan-Egbert Sturm and James Raymond Vreeland, Does Membership on the UN Security Council Influence IMF Decisions? Evidence from Panel Data, September 2006

1809 Prabir De, Regional Trade in Northeast Asia: Why do Trade Costs Matter?, September 2006

1810 Antonis Adam and Thomas Moutos, A Politico-Economic Analysis of Minimum Wages and Wage Subsidies, September 2006

1811 Guglielmo Maria Caporale and Christoph Hanck, Cointegration Tests of PPP: Do they also Exhibit Erratic Behaviour?, September 2006

1812 Robert S. Chirinko and Hisham Foad, Noise vs. News in Equity Returns, September 2006

1813 Oliver Huelsewig, Eric Mayer and Timo Wollmershaeuser, Bank Behavior and the Cost Channel of Monetary Transmission, September 2006

1814 Michael S. Michael, Are Migration Policies that Induce Skilled (Unskilled) Migration Beneficial (Harmful) for the Host Country?, September 2006

1815 Eytan Sheshinski, Optimum Commodity Taxation in Pooling Equilibria, October 2006

1816 Gottfried Haber and Reinhard Neck, Sustainability of Austrian Public Debt: A Political Economy Perspective, October 2006

1817 Thiess Buettner, Michael Overesch, Ulrich Schreiber and Georg Wamser, The Impact of Thin-Capitalization Rules on Multinationals' Financing and Investment Decisions, October 2006

1818 Eric O’N. Fisher and Sharon L. May, Relativity in Trade Theory: Towards a Solution to the Mystery of Missing Trade, October 2006

1819 Junichi Minagawa and Thorsten Upmann, Labor Supply and the Demand for Child Care: An Intertemporal Approach, October 2006

1820 Jan K. Brueckner and Raquel Girvin, Airport Noise Regulation, Airline Service Quality, and Social Welfare, October 2006

1821 Sijbren Cnossen, Alcohol Taxation and Regulation in the European Union, October 2006

1822 Frederick van der Ploeg, Sustainable Social Spending in a Greying Economy with Stagnant Public Services: Baumol’s Cost Disease Revisited, October 2006

1823 Steven Brakman, Harry Garretsen and Charles van Marrewijk, Cross-Border Mergers \& Acquisitions: The Facts as a Guide for International Economics, October 2006 